


\section{DISCLAIMER}

This report was prepared as an account of work sponsored by an agency of the United States Government. Neither the United States Government nor any agency Thereof, nor any of their employees, makes any warranty, express or implied, or assumes any legal liability or responsibility for the accuracy, completeness, or usefulness of any information, apparatus, product, or process disclosed, or represents that its use would not infringe privately owned rights. Reference herein to any specific commercial product, process, or service by trade name, trademark, manufacturer, or otherwise does not necessarily constitute or imply its endorsement, recommendation, or favoring by the United States Government or any agency thereof. The views and opinions of authors expressed herein do not necessarily state or reflect those of the United States Government or any agency thereof. 


\section{DISCLAIMER}

Portions of this document may be illegible in electronic image products. Images are produced from the best available original document. 


\title{
Annual Environmental Monitoring Report: Calendar Year 1975
}

\author{
Billy M. Farmer, Bobby Robinson, \\ and Daniel G. Carfagno
}

Issued: April 26, 1976

\begin{abstract}
NOTICE
This report was prepared as an account of work sponsored by the United States Government. Neither the United States nor the United States Energy Research and Dovelopment Administration, nor any of their employees, nor any of their contractors, subcontractors, or their employees, makes any warranty, express or implied, or assumes any legal liability or responsibility for the accuracy, completeness or usefulness of any information, apparatus, product or process disclosed. or represents that its use would not infringe privately owned rights.

PRINTED IN THE UNITED STATES OF AMERICA

Available from

- National Technical Information Service

U. S. Department of Commerce 5285 Port Royal Road

Springfield, Virginia 22161

Price: Printed Copy $\$ 4.00$ : Microfiche $\$ 2.25$
\end{abstract}

\section{MONSANTO RESEARCH CORPORATION}

A Subsidiary of Monsanto Company

\section{MOUND LABORATORY}

Mianisburg, Ohio $\quad 45312$

operated for

\section{UNITED STATES ENERGY RESEARCH AND DEVELOPMENT ADMINISTRATION}

U. S. Government Contract No. E-33-1-GEN-53 


\section{Foreword}

This report was prepared by the Environmental Control Section of the Personnel Safety, Waste Management, and Environmental Control Function in the Administrative Services Department at Mound Laboratory. Sample analyses and data reduction were performed by the Radiological Surveillance group of the Environmental Control Section. Particulate samples off-site are collected by the Air Pollution Control Section of the Montgomery County Combined General Health District which acts as the Regional Air Pollution Control Agency in this region for the Ohio Environmental Protection Agency. 


\section{Table of Contents}

$\underline{\text { Page }}$

INTRODUCTION

SUMMARY . . . . . . . . . . . . . . . . . . . . . . . . 8

ENVIRONMENTAL SURVEILLANCE . . . . . . . . . . . . . . 10

Alr - Radioactive . . . . . . . . . . .. . . . 10

Air - Nonradioactive . . . . . . . . . . . . . . . 17

Water - Radioactive . . . . . . . . . . . . . 17

Water - Nonradioactive . . . . . . . . . . . . . 24

Foodstuffs and Vegetation - Radioactive . . . . . . . 25

Soil and Silt - Radioactive . . . . . . . . . . . . 27

EVALUATION OF POTENTIAL DOSE TO THE PUBLIC . . . . . . . . 31

ACKNOWLEDGEMENT . . . . . . . . . . . . . . . . . . . 36

REFERENCES . . . . . . . . . . . . . . . . . . . . 37

APPENDIX

Applicable standards . . . . . . . . . . . . 39

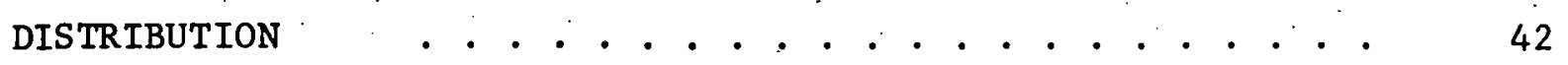


THIS PAGE

WAS INTENTIONALLY

LEFT BLANK 


\section{Introduction}

Mound Laboratory is situated on 180.acres of land in Miamisburg, Ohio. This location is approximately $16 \mathrm{~km}$ (10 mi) southwest of Dayton. The predominant geographical feature in the five-county region surrounding the Laboratory is the Great Miami River which flows from the northeast to the southwest through Miamisburg. This river valley area is generally highly industrialized. The remainder of the region is predominantly agricultural with some light industry and scattered residential communities. The location and population of these communities are shown in Figure 1. The primary agricultural activity in the area is raising field crops such as corn and soybeans. Approximately $10 \%$ of the land area in agricultural use is devoted to pasturing livestock. ${ }^{1}$

Weather conditions in the area are described as moderate. The average annual precipitation is approximately $91 \mathrm{~cm}$ (36 in.) and is evenly distributed throughout the year. Winds are predominately from the south or west except during the summer months when a higher frequency is recorded from out of the southwest. The wind speed averages about $16 \mathrm{~km} / \mathrm{hr}(10 \mathrm{mi} / \mathrm{hr})$ annually. ${ }^{2}$

Mound Laboratory began operations in 1949. Its mission currently includes research, development, engineering, and production of components for the ERDA weapons program; research, development, and production of explosive materials; separation, purification, and sale of stable isotopes of the noble gases; and development, design, and fabrication of radioisotopic heat sources for med1cal application and space exploration. The radionuclides of primary concern currently being handled include plutonium-238 and tritium.

Conformance to regulations prescribed by ERDA pertaining to the safety of employees and the public have been demonstrated during the history of Mound Laboratory. The fundamental objectives of the Mound Laboratory Environmental Control Program, which has been in existence throughout the history of the Laboratory, is the containment of radioactive effluents to levels well within the existing standards. As part of this control function, effluents are monitored and controlled at each operating step resulting in detection of low-leve1 releases of airborne or liquid wastes to the environment. Because of this early detection, control techniques can be taken thus ensuring that concentrations are well within existing standards. 


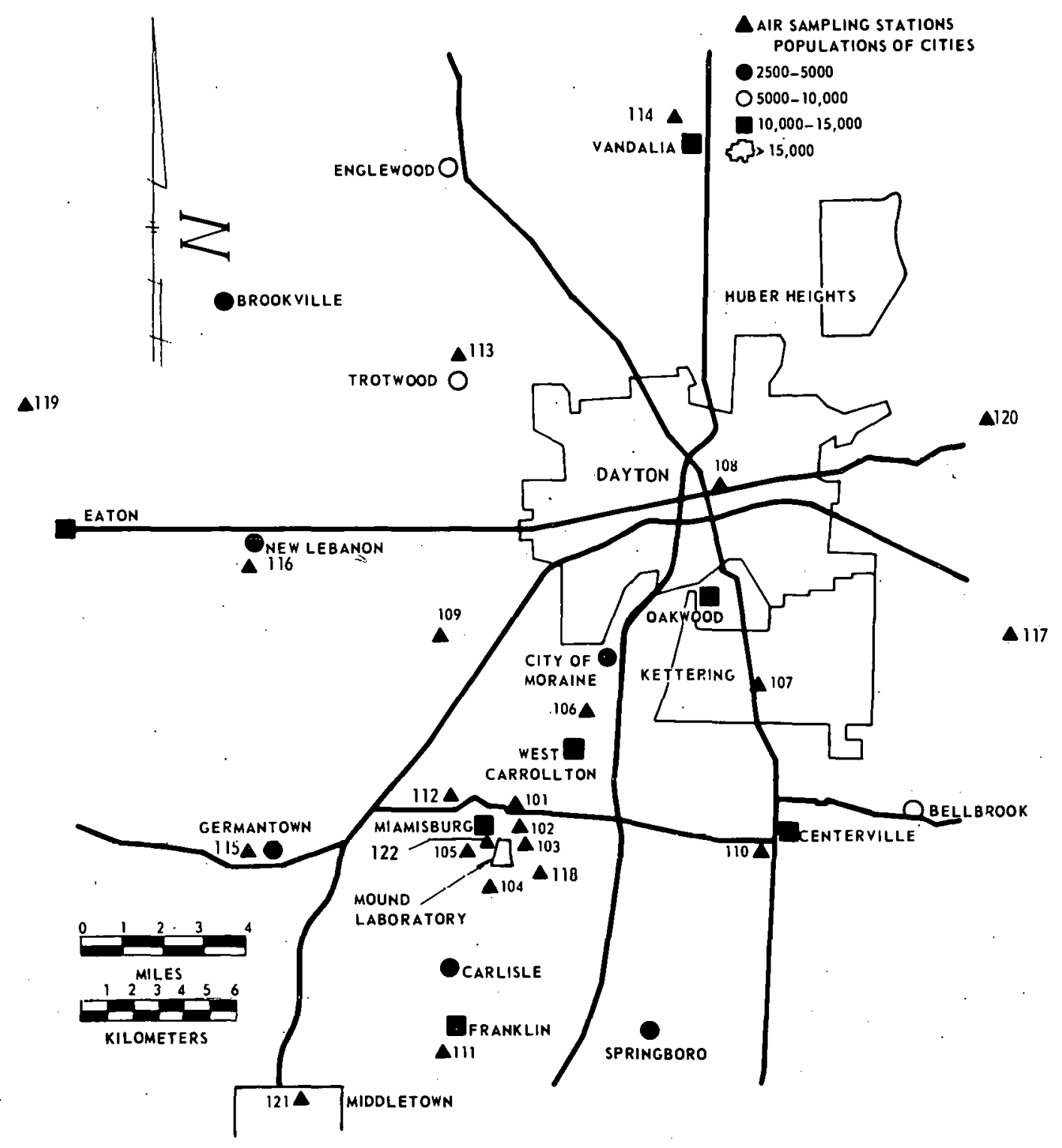

FIGURE 1 - Off-site air sampling locations 
As part of the Environmental Program monitoring functions, air, water, foodstuff, and soil samples are collected from the environment at distances up to $45 \mathrm{~km}$ (28 mi) from the Laboratory boundaries. These samples are analyzed for the specific radionuclides handled at the Laboratory.

Radionuclides in particulate form are removed from air effluents by high efficiency particulate air filters (HEPA). The air effluents are filtered first at the points of origin, i.e. glove boxes, and just prior to the release point, i.e. the stack. The filtering system at the stack consists of two banks of HEPA filters in series, each with a collection efficiency of $99.9 \%$. Radionuclides are removed from liquid effluents such as process waste liquids by chemical processing. Solid radioactive wastes are packaged and shipped off-site for burial at ERDA-approved burial sites. Airborne and liquid wastes generated in the processing of explosive materials are collected and disposed of according to the Army Materiel Command Regulation 385-100.

A new sanitary waste treatment plant was placed in operation during 1975. The plant provides secondary treatment in accordance with EPA requirements ${ }^{3}$ using an activated sludge process operating in the extended aeration mode. A11 domestic sewage generated on-site is treated in this facility. The influent and effluent at the sewage treatment plant are also moni.tored for radioactivity to ensure no undetected release can occur to the environment via the sanitary sewage plant. The digested sludge from the sewage plant is shipped off-site for burial to an ERDA-approved burlal site to ensure that no contaminated sludge. is released to the environment. Nonradioactive solid wastes are disposed of according to a recycling and reclamation program implemented during the first quarter of 1974. White paper, scrap metal, and wood are sold for reclamation. General refuse is transported to the Franklin Reclamation Center, Franklin, Ohio, for processing and eventual use in recycled products. Waste solvents and chemicals are removed off-site by a commercial industrial-waste-disposal firm.

A quality control program for environmental analytical procedures has been in effect for several years. There are two parts to the program: internal and external. The internal portion consists of blank and duplicate analyses for each group of samples. The blank results have been consistently small and insignificant in comparison with sample results. The duplicate results for 1975 were also satisfactory. The external portion of the program consists of sending duplicate samples to an independent lahnratory. These results for 1975 were also satisfactory. In summary, results indicate good analytical control.

The results of the analyses for calendar year 1975 are provided in this report. Error limits, when given, reflect uncertainties in the data due to counting statistics at the $95 \%$ confidence level. 


\section{Summary}

The local environment surrounding Mound Laboratory was monitored for tritium and plutonium-238 released by Mound Laboratory. The results are reported for calendar year 1975. The environmental parameters analyzed included air, water, foodstuffs, soil, and silt. For radioactive species, the average concentrations of plutonium-238 and tritium were within the stringent standards adopted by the U.S. Energy Research and Development Administration. Data concerning nonradioactive species in air and water are also presented and compared to federal, state, and local standards, where applicable.

The average concentrations of plutonium-238 and tritium measured in air during $\mathrm{CY}-1975$ were $<0.64 \times 10^{-17} \mu \mathrm{Ci} / \mathrm{ml}$ and $<0.89 \times 10^{-11} \mu \mathrm{Ci} / \mathrm{ml}$, respective1y. These correspond to $<0.03 \%$ and $<0.01 \%$ of their respective Radioactivity Concentration Guides (RCG's). The RCG's and their explanation are given in the Appendix.

The average concentrations of plutonium-238 and tritium in the Great Miami River during $\mathrm{CY}-1975$ were $0.3 \times 10^{-10} \mu \mathrm{Ci} / \mathrm{ml}$ and $<1.9 \times 10^{-6}$ $\mu \mathrm{Ci} / \mathrm{ml}$, respectively. These correspond to $0.002 \%$ and $<0.19 \%$ of their respective RCG's.

Additiona11y, data concerning tritium and plutonium-238 in surface water, community drinking water, foodstuffs, soil, and silt are presented. From the analyzed data; there is no evidence of other than negligible, uptakes of radioactive species from air, water, soil, or silt by plant or animal 1ife. ${ }^{4}$ There is also no evidence of other than negligible reentrainment of radioactive species from soil or silt.

A1so included is a plutonium-238 deposition inventory in waterways and a preliminary soil inventory of plutonium-238 based on soil core sampling around Mound Laboratory..$^{5}$ This study gives a preliminary evaluation in quantities of plutonium-238 in the environment from Laboratory operations.

Mound Laboratory has been issued a National Pollutant Discharge Elimination System discharge permit. Analyses indicate general compliance with permit conditions with the exception of three oil and grease values. These values are reported, but are suspect because of analytical problems. All results indicate that Mound effluent streams have no significant effect on the Great Miami River and certainly do not 
cause Ohio Stream Standards to be exceeded.

These data demonstrate our compliance with various regulatory agency standards and that the operation of Mound Laboratory has a negligible effect on the environment. 


\section{Environmental Surveillance}

\section{AIR - RADIOACTIVE}

An off-site air sampling network consisting of 21 continuously operating air-sampling stations ( 22 for plutonium-238) was used for the first six months of CY-1975. Because of funding reductions, however, this number was reduced to 12 (13 for plutonium-238) during the last six months of CY-1975. During the first half of the year, eight sampling stations were located within a $1.6-\mathrm{km}(1-\mathrm{mi})$ radius of the Laboratory. The original 13 samplers located in or near population centers were reduced to four during the last half of the year. The remaining sampler (非19) is still used and is approximately $44.8 \mathrm{~km}(28 \mathrm{mi})$ from the Laboratory in the least prevailing wind direction. This site should receive no measurable contribution from Mound operations and serves as a baseline sample for comparison purposes. The samplers currently in operation sample critical distances and directions based on the diffusion mode1 developed for Mound Laboratory. The sampling sites are shown in Figure 1 .

Two types of samples are collected at each sampling station, a particulate air sample for plutonium-238 analysis and a bubbler sample for tritium oxide analysis. The particulate samp1,e is collected on a 200-mm diameter Microsorban disk by a continuously operating (24 hr, 7 days per week) high-volume air sampler. The air is sampled at the average rate of $1.3 \times 10^{6} \mathrm{~cm}^{3} / \mathrm{min}\left(\sim 45 \mathrm{ft}^{3} / \mathrm{min}\right)$. The Microsorban disk is changed weekly thus represents a sample of approximately $13,000 \mathrm{~m}^{3}$ of air. Plutonium-238 analyses are performed on a monthly composite.

The analytical scheme for plutonium-238 incorporates the following basic steps: addition of a known amount of plutonium-242 tracer, ignition to $600^{\circ} \mathrm{C}$, dissolution with nitric acid, separation of plutonium with anion exchange resin, electrodeposition of plutonium, and finally alpha spectrometry. The results reported represent total concentrations of the analyzed radionuclides including contribution from atmospheric fallout.

The average off-site plutonium-238 air concentration was $<0.64 \times 10^{-17}$ $\mu \mathrm{Ci} / \mathrm{ml}$ which is $<0.03 \%$ of the RCG. The RCG used for comparison is the guide for the soluble form of the isotope and for the general population. This is the most restrictive RCG for plutonium-238 and is applied since 
the solubility of the measured particles in the human body is unknown. The results are summarized in Table 1 . Samples reported as less than (<) the Minimum Detection Limit (MDL) are, for averaging purposes, considered to be the value of MDL. Actually, the true value lies somewhere between natural background and MDL.

Also included in Table 1 are ratios of plutonium-238 to plutonium-239 for each sampling location. A ratio greater than $\sim 0.2$ would indicate a concentration of plutonium-238 greater than that from atmospheric fallout and thus would indicate influence from Laboratory operations. ${ }^{6}$

The gas bubbler sample is also collected on a continuous basis by bubbling air at approximately $3 \times 10^{3} \mathrm{~cm}^{3} / \mathrm{min}$ through $200 \mathrm{ml}$ of ethylene glycol. Ethylene glycol is used because this material eliminates evaporation and freezing problems associated with sample collection. ${ }^{7}$ Any tritium (oxide) in the air is collected in the solution. The sampling and analysis are directed to tritium oxide since the RCG for the oxide is 200 times more restrictive than for elemental tritium. ${ }^{8}$ A sample representing $\sim 30 \mathrm{~m}^{3}$ of air is collected and an aliquot representing $1.5 \mathrm{~m}^{3}$ is counted in a liquid scintillation spectrometer. The average concentration of tritium oxide measured during CY-1975 was less than $0.89 \times 10^{-11} \mu \mathrm{Ci} / \mathrm{m} 1$ which is less than $0.01 \%$ of RCG. The RCG used for comparison is the guide for the general population and for soluble form, which is the most restrictive RCG for tritium. The results are summarized in Table 2 .

Table 3 shows values of background for plutonium-238 and tritium in air.

An on-site perimeter network consisting of five continuous, high-volume air samplers is used to further assess the effectiveness of control systems. The on-site sampling locations are shown in Figure 2. Particulate samples are collected by the on-site samplers at approximately the same flow rate as the off-site samplers, i.e. $1.3 \times 10^{6} \mathrm{~cm}^{3} / \mathrm{min}$, and are analyzed in the same manner. The tritium samplers operate at slightly less air flow, i.e. approximately $2 \times 10^{3} \mathrm{~cm}^{3} / \mathrm{min}$, and are analyzed in the same manner as off-site samplers.

The average plutonium-238 concentration measured on-site was $28 \times 10^{-17}$ $\mu \mathrm{Ci} / \mathrm{m} 1$ which is $0.4 \%$ of the RCG. The results are summarized in Table 4 .

The average on-site tritium oxide concentration was $<3.0 \times 10^{-11} \mu \mathrm{Ci} / \mathrm{ml}$ which is $<0.02 \%$ of the RCG. The results are summarized in Table 5 .

The RCG's used for on-site comparisons are those applicable for incidently exposed individuals in the population. The total amounts of plutonium-238 and tritium discharged to the atmosphere were $0.022 \mathrm{mCi}$ and $8,859 \mathrm{Ci}$, respectively. Comparison of these quantities to the RCG is not valid. 
Table 1

CONCENTRATIONS OF PLUTONIUM IN AIR AT OFF-SITE SAMPLING LOCATIONS IN 1975

\begin{tabular}{|c|c|c|c|c|c|c|c|c|c|}
\hline \multirow[b]{2}{*}{ Location } & \multirow[b]{2}{*}{$\begin{array}{c}\text { Number of } \\
\text { Samples } \\
\end{array}$} & \multicolumn{2}{|c|}{${ }^{23}{ }^{8} \mathrm{Pu}$} & \multicolumn{2}{|c|}{${ }^{2} 3^{8} \mathrm{Pu}$} & \multicolumn{4}{|c|}{$239 \mathrm{Pu}$} \\
\hline & & $\left(10^{-17^{\mathrm{Ra}}}\right.$ & $\begin{array}{l}\text { nge } \\
\mu \mathrm{Ci} / \mathrm{m} 1)\end{array}$ & $\begin{array}{l}\text { Aver } \\
\left(10^{-17}\right. \\
\end{array}$ & $\begin{array}{l}g^{a, d} \\
\mu \mathrm{Ci} / \mathrm{ml})\end{array}$ & $\begin{array}{l}\text { Percent } \\
\text { of RCG }\end{array}$ & $\begin{array}{r}\text { Aver } \\
\left(10^{-17}\right. \\
\end{array}$ & $\begin{array}{l}\mathrm{age}^{\mathrm{c}, \mathrm{d}} \\
\mu \mathrm{Ci} / \mathrm{ml})\end{array}$ & ${ }^{238} \mathrm{Pu} / /^{239} \mathrm{Pu}$ \\
\hline 101 & 52 & 0.37 & -5.6 & 2.3 & \pm 0.22 & 0.12 & 2.9 & \pm 0.25 & 0.79 \\
\hline 102 & 52 & 0.58 & -3.0 & 1.4 & \pm 0.17 & 0.07 & 2.9 & \pm 0.25 & 0.48 \\
\hline 103 & 52 & 0.45 & -3.1 & 1.3 & \pm 0.17 & 0.07 & 2.3 & \pm 0.22 & 0.57 \\
\hline 104 & 52 & 0.23 & -9.4 & 1.4 & \pm 0.17 & 0.07 & 2.2 & \pm 0.22 & 0.64 \\
\hline 105 & 41 & 0.08 & -5.4 & 0.9 & \pm 0.14 & 0.05 & 1.9 & \pm 0.20 & 0.49 \\
\hline 106 & 13 & 0.27 & -0.35 & 0.3 & \pm 0.08 & 0.02 & 3.8 & \pm 0.29 & 0.08 \\
\hline 107 & 25 & 0.16 & -1.6 & 0.6 & \pm 0.12 & 0.03 & 3.6 & \pm 0.28 & 0.17 \\
\hline 108 & 52 & 0.11 & -1.6 & 0.7 & \pm 0.13 & 0.04 & 1.9 & \pm 0.20 & 0.39 \\
\hline 109 & 25 & 0.08 & -0.86 & 0.3 & \pm 0.08 & 0.02 & 3.7 & \pm 0.28 & 0.09 \\
\hline 110 & 52 & $<0.079$ & -0.47 & $<0.2$ & \pm 0.07 & $<0.01$ & 1.9 & \pm 0.20 & $<0.12$ \\
\hline 111 & 52 & $<0.079$ & -0.53 & $<0.3$ & \pm 0.08 & $<0.02$ & 2.2 & \pm 0.22 & $<0.15$ \\
\hline 112 & 52 & 0.12 & -0.49 & 0.3 & \pm 0.15 & 0.02 & 3.1 & \pm 0.26 & 0.11 \\
\hline 113 & 25 & 0.14 & -0.18 & 0.1 & \pm 0.06 & 0.01 & 4.0 & \pm 0.29 & 0.04 \\
\hline 114 & 22 & 0.15 & -0.21 & 0.1 & \pm 0.06 & 0.01 & 4.0 & \pm 0.29 & 0.05 \\
\hline 115 & 52 & $<0.079$ & -0.38 & $<0.1$ & \pm 0.06 & $<0.01$ & 2.6 & \pm 0.24 & $<0.07$ \\
\hline 116 & 25 & 0.10 & -0.13 & 0.1 & \pm 0.05 & 0.01 & 3.5 & \pm 0.28 & 0.03 \\
\hline 117 & 21 & 0.15 & -0.74 & 0.4 & \pm 0.10 & 0.02 & 3.4 & \pm 0.27 & 0.14 \\
\hline 118 & 52 & 0.14 & -0.76 & 0.4 & + \pm 0.10 & 0.02 & 1.8 & \pm 0.20 & 0.24 \\
\hline 119 & 50 & $<0.079$ & -0.20 & $<0.1$ & \pm 0.06 & $<0.01$ & 1.9 & \pm 0.20 & $<0.07$ \\
\hline 120 & 25 & 0.17 & -0.18 & 0.1 & $3 \pm 0.06$ & 0.01 & 3.5 & \pm 0.28 & 0.05 \\
\hline 121 & 25 & 0.14 & -0.18 & 0.1 & $; \pm 0.06$ & 0.01 & 3.7 & \pm 0.28 & 0.04 \\
\hline 122 & 44 & 0.64 & -7.4 & 1.7 & \pm 0.19 & 0.09 & 1.6 & \pm 0.19 & 1.1 \\
\hline
\end{tabular}

${ }^{a}$ Minimum Detection Limit (MDL) for ${ }^{238} \mathrm{Pu}$ in air is $0.079 \times 10^{-17} \mu \mathrm{Ci} / \mathrm{ml}$ which is $0.004 \%$ of the RCG.

${ }^{\mathrm{b}}$ Radioactivity Concentration Guide $(\mathrm{RCG})=2000 \times 10^{-17} \mu \mathrm{Ci} / \mathrm{ml}$ for the soluble form of ${ }^{238} \mathrm{Pu}$ and the general population.

${ }^{c}$ Minimum Detection Limit (MDL) for ${ }^{239} \mathrm{Pu}$ in air is $0.046 \times 10^{-17} \mu \mathrm{Ci} / \mathrm{ml}$.

${ }^{d}$ Error limits are counting statistics only at $95 \%$ C.L. 
Table 2

CONCENTRATIONS OF TRITIUM OXIDE IN AIR AT OFF-SITE SAMPLING LOCATIONS IN 1975

\begin{tabular}{|c|c|c|c|c|c|c|}
\hline Location & $\begin{array}{c}\text { Number of } \\
\text { Samples } \\
\end{array}$ & $\begin{array}{r}\text { Rar } \\
\left(10^{-11}\right. \\
\end{array}$ & $\begin{array}{l}\text { gge } \\
\mu \mathrm{Ci}(\mathrm{m} I)\end{array}$ & $\begin{array}{r}\text { Avera } \\
\left(10^{-11} \mu\right. \\
\end{array}$ & $\begin{array}{l}g e^{a, c} \\
\mathrm{Ci} / \mathrm{ml}) \\
\end{array}$ & $\begin{array}{l}\text { Percent } \\
\text { of } \mathrm{RCG}^{\circ} \\
\end{array}$ \\
\hline 101 & 52 & $<0.72$ & -4.2 & $<1.3$ & \pm 0.27 & $<0.02$ \\
\hline 102 & 52 & $<0.72$ & -4.9 & $<1.6$ & \pm 0.30 & $<0.02$ \\
\hline 103 & 52 & $<0.72$ & -5.2 & $<1.4$ & \pm 0.28 & $<0.02$ \\
\hline 104 & 52 & $<0.72$ & -2.7 & $<0.9$ & \pm 0.23 & $<0.01$ \\
\hline 105 & 52 & $<0.72$ & -6.8 & $<1.1$ & \pm 0.25 & $<0.02$ \\
\hline 106 & 27 & $<0.72$ & -1.1 & $<0.73$ & \pm 0.20 & $<0.01$ \\
\hline 107 & 27 & $<0.72$ & -1.4 & $<0.79$ & \pm 0.21 & $<0.01$ \\
\hline 108 & 52 & $<0.72$ & -2.1 & $<0.78$ & \pm 0.21 & $<0.01$ \\
\hline 109 & 27 & $<0.72$ & -1.8 & $<0.80$ & \pm 0.21 & $<0.01$ \\
\hline 110 & 52 & $<0.72$ & -1.6 & $<0.74$ & \pm 0.21 & $<0.01$ \\
\hline 111 & 52 & $<0.72$ & -1.3 & $<0.74$ & \pm 0.21 & $<0.01$ \\
\hline 112 & 52 & $<0.72$ & -4.6 & $<1.0$ & \pm 0.21 & $<0.01$ \\
\hline 113 & 27 & $<0.72$ & -1.3 & $<0.76$ & \pm 0.21 & $<0.01$ \\
\hline 114 & 23 & $<0.72$ & -1.4 & $<0.77$ & \pm 0.21 & $<0.01$ \\
\hline 115 & 52 & $<0.72$ & -1.7 & $<0.75$ & \pm 0.21 & $<0.01$ \\
\hline 116 & 27 & $<0.72$ & -1.2 & $<0.74$ & \pm 0.21 & $<0.01$ \\
\hline 117 & 23 & $<0.72$ & -1.3 & $<0.77$ & \pm 0.21 & $<0.01$ \\
\hline 118 & 52 & $<0.72$ & -1.8 & $<0.89$ & \pm 0.23 & $<0.01$ \\
\hline 119 & 51 & $<0.72$ & -1.3 & $<0.74$ & \pm 0.21 & $<0.01$ \\
\hline 120 & 27 & $<0.72$ & -0.87 & $<0.72$ & \pm 0.20 & $<0.01$ \\
\hline 121 & 27 & $<0.72$ & -1.0 & $<0.73$ & \pm 0.20 & $<0.01$ \\
\hline
\end{tabular}

Minimum Detection Limit (MDL) for tritium oxide in air is $0.72 \times 10^{-11} \mu \mathrm{Ci} / \mathrm{ml}$, which is $0.01 \%$ of the RCG.

${ }^{b}$ Radioactivity Concentration Guide (RCG) $=7000 \times 10^{-11} \mu \mathrm{Ci} / \mathrm{m} 1$ for the general population and for soluble form of tritium.

${ }^{\circ}$ Error limits are counting: statistics only at $95 \%$ C.L.

Table 3

CONCENTRATIONS OF BACKGROUND LEVELS OF TRITIUM AND PLUTONIUM-238 IN 1975

Plutonium-238 in Air

P1utonium-238 in Surface Water ${ }^{b}$

Tritium-Oxide in Air ${ }^{c}$

Tritium-0xide in Surface Water ${ }^{d}$
$0.3 \pm 0.1 \times 10^{-17} \mu \mathrm{Ci} / \mathrm{m} 1$

$7 \times 10^{-13} \mu \mathrm{C} 1 / \mathrm{ml}$

$0.2 \times 10^{-11} \mu \mathrm{Ci} / \mathrm{ml}$

$0.5 \pm 0.2 \times 10^{-6} \mu \mathrm{Ci} / \mathrm{m} 1$

References 12, 13

${ }^{b}$ Reference 14

${ }^{\mathrm{c}}$ Reference 15

${ }^{\mathrm{d}}$ Reference 16 


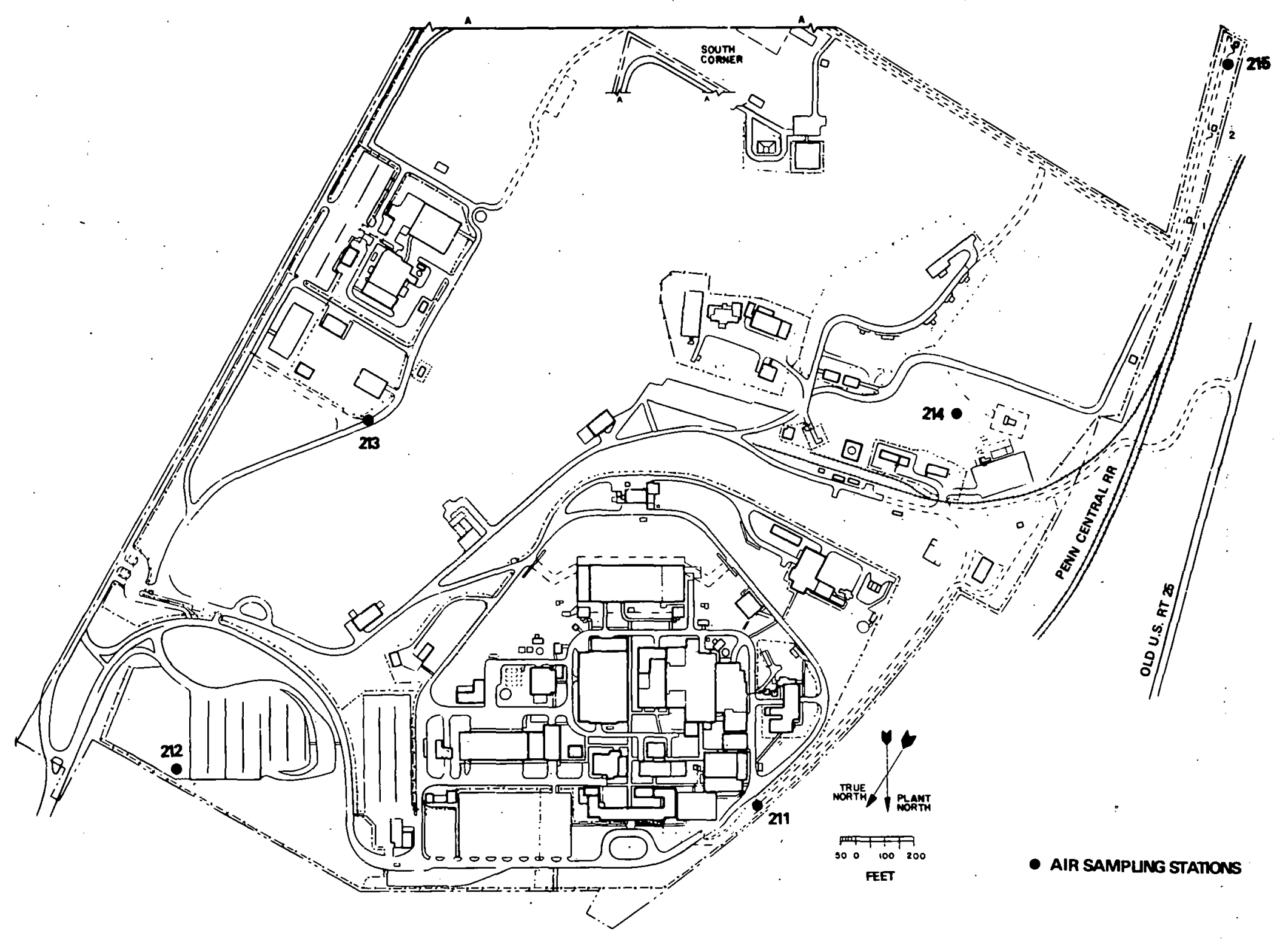

FIGURE 2 - On-site air sampling locations 
Table 4

CONCENTRATION OF ${ }^{2.38} \mathrm{Pu}$ IN AIR AT ON-SITE SAMPLING LOCATIONS IN 1975

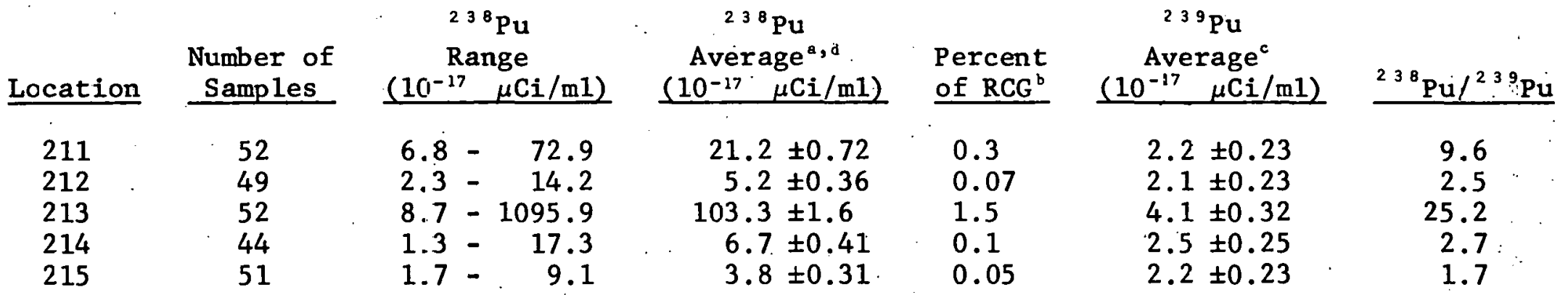

${ }^{a}$ Minimum Detection Limit (MDL) for ${ }^{23}{ }^{8} \mathrm{Pu}$ in air is $0.089 \times 10^{-17} \mu \mathrm{Ci} / \mathrm{m} 1$ which is $0.0012 \%$ of the RCG.

${ }^{b}$ Radioactivity Concentration Guide (RCG) $=7000 \times 10^{-17} \mu \mathrm{Ci} / \mathrm{m} 1$ for the soluble form of plutonium-238 for individuals in the population.

${ }^{c}$ Minimum Detection Limit (MDL) for ${ }^{2}{ }^{39} \mathrm{Pu}$ is $0.052 \times 10^{-17} \mu \mathrm{Ci} / \mathrm{m} 1$.

${ }^{d}$ Error 1 imits are counting statistics only at $95 \%$ C.L. 
Table 5

CONCENTRATION OF TRITIUM OXIDE IN AIR AT ON-SITE SAMPLING LOCATIONS IN 1975

\begin{tabular}{|c|c|c|c|c|}
\hline \multirow{2}{*}{ Location } & \multirow{2}{*}{$\begin{array}{c}\text { Number of } \\
\text { Samples } \\
\end{array}$} & Range & Average $^{a, c}$ & \multirow{2}{*}{$\begin{array}{l}\text { Percent } \\
\text { of } \mathrm{RCG}^{\mathrm{b}}\end{array}$} \\
\hline & & $\mu \mathrm{Ci} / \mathrm{m} 1)$ & $\left(10^{-11} \mu \mathrm{Ci} / \mathrm{m} 1\right)$ & \\
\hline 211 & 52 & $<1.2-10.0$ & $<3.1 \pm 0.55$ & $<0.02$ \\
\hline 212 & 50 & $<1.2-$ & $<3.3 \pm 0.56$ & $<0.02$ \\
\hline 213 & 52 & $<1.2-11.7$ & $<3.1 \pm 0.55$ & $<0.02$ \\
\hline 214 & 52 & $<1.2-29.0$ & $<3.4 \pm 0.58$ & $<0.02$ \\
\hline 215 & 51 & $<1.2-8.3$ & $<2.0 \pm 0.44$ & $<0.01$. \\
\hline
\end{tabular}

"Minimum Detection Limit (MDL) for tritium oxide in air is $1.22 \times 10^{-11} \mu \mathrm{Ci} / \mathrm{m} 1$ which is $0.006 \%$ of the RCG.

${ }^{b}$ Radioactivity Concentration Guide $(R C G)=20,000 \times 10^{-11} \mu \mathrm{Ci} / \mathrm{ml}$ for individuals in the population and soluble form of tritium.

${ }^{c}$ Error limits are counting statistics only at $95 \%$ C.L. 


\section{AIR - NONRADIOACTIVE}

The Mound steam power supply has been converted from fuel oil to natural gas on an interruptable basis. During unusually cold weather, natural gas supply to Mound is interrupted and fuel oil with much less than $1 \%$ sulfur content is burned. Except for these occasions, virtually all sulfur dioxide emissions have been eliminated. None of the present operations at Mound Laboratory involve amounts of material which would lead to significant particulate, carbon monoxide, photochemical oxidant, or hydrocarbon emissions from stationary sources. Therefore, no sampling for these nonradioactive pollutants is done at this time.

\section{WATER - RADIOACTIVE}

Water sampling locations along the bank of the Great Miami River were selected according to guidelines proposed by the U.S. EPA. ${ }^{9}$ The locations, shown in Figure 3, provide samples which are representative of river water after suitable mixing of the effluent from Mound has occurred. Water samples are collected at these locations five days per week and are subjected to specific analyses for plutonium-238 and tritium oxide.

The plutonium-238 river water analyses have been upgraded to allow lower detection of plutonium-238 in water. Large volume water samples are analyzed by compositing daily samples for a semiannual analysis. The average volume of water analyzed was 19 liters. The average concentration of plutonium-238 measured in the Great Miami River was $0.3 \times 10^{-10}$ $\mu \mathrm{Ci} / \mathrm{ml}$ which is $0.002 \%$ of the RCG for the general population and the most restrictive form (soluble) of plutonium-238. These results are summarized in Table 6 .

Tritium oxide analyses are performed on a weekly composite of daily samples. The average concentration of tritium oxide measured in the Great Miaml River was $<1.9 \times 10^{-6} \mu \mathrm{Ci} / \mathrm{ml}$ which is $<0.2 \%$ of the RCG for the general population and for the most restrictive form of tritium. The resul.ts are sumarized in Table 7 .

Results of plutonium-23.8 and tritium analyses for three off-site sampling locations on the abandoned Miami-Erie Canal and adjacent ponds are reported in Tables 8 and 9, respectively. These values represent levels from the site drainage ditch which discharges into the off-site canal-pond system prior to mixing with the Great Miami River. These values, as expected, are higher than those concentrations found in the Great Miami River where mixing and dilution occur.

The total amounts of plutonium-238, tritium, and uranium-233 discharged to the Great Miami River were $18 \mathrm{mCi}, 58 \mathrm{Ci}$, and $17 \mathrm{mCi}$, respectively. These values in terms of RCG's are $0.3 \%, 1.8 \%$ and $0.05 \%$ of the most restrictive RCG for individuals in the population. From the uranium233 concentrations found in the effluent streams; estimated concentrations off-stte from Mưnd operations would be negligible. Thi.s can be 


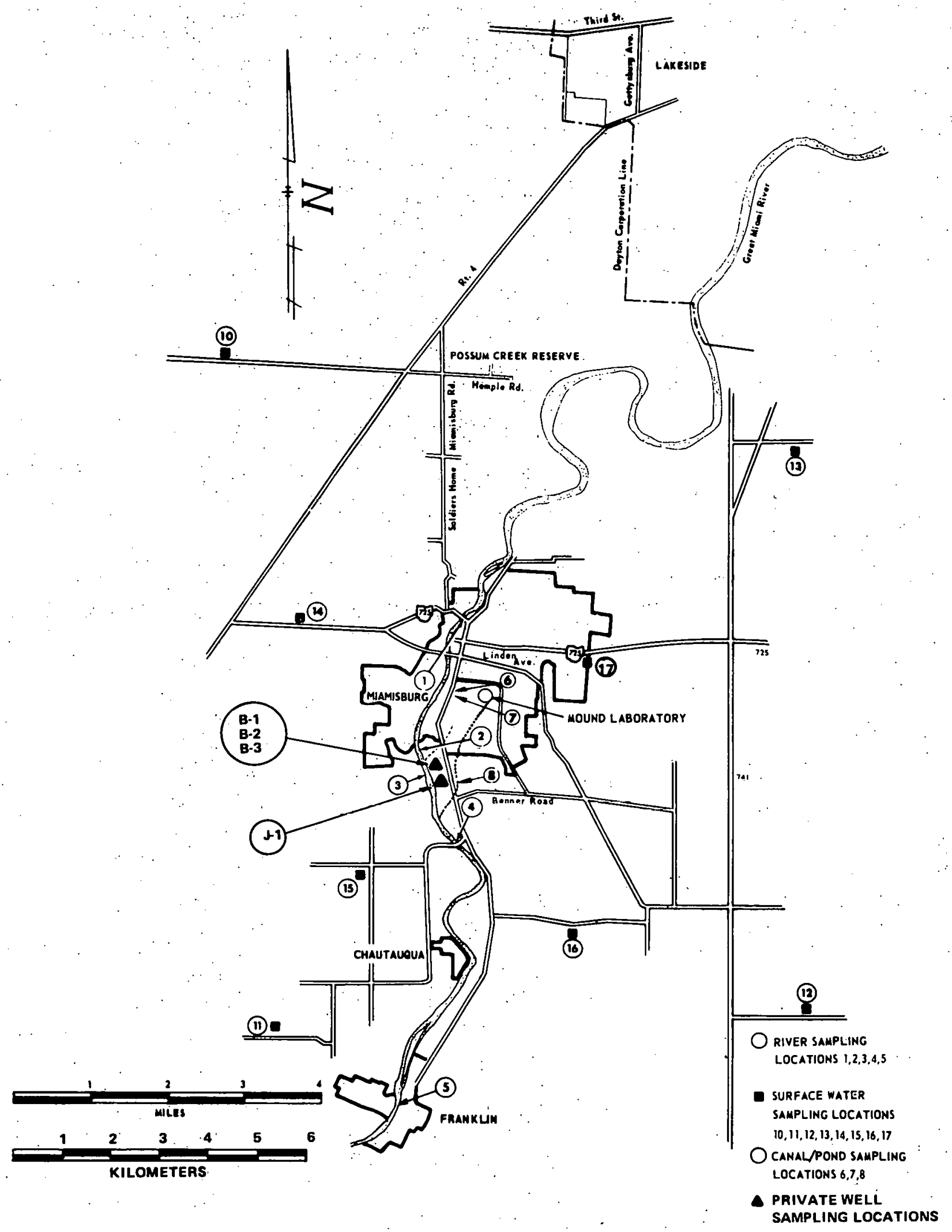

FIGURE 3 - Off-site water sampling locations 
Table 6

CONCENTRATION OF ${ }^{238} \mathrm{Pu}$ IN

THE GREAT MIAMI RIVER IN 1975

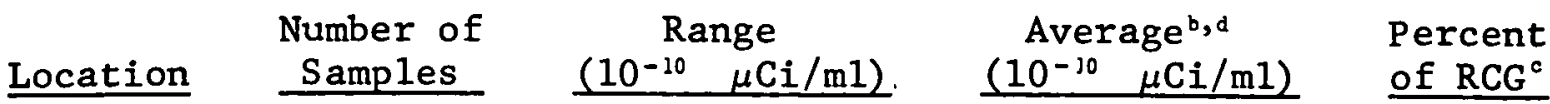

$\begin{array}{llccc}1 & 210 & 0.15-0.23 & 0.19 \pm 0.02 & 0.0010 \\ 2 & 210 & 0.32-0.35 & 0.34 \pm 0.03 & 0.0017 \\ 3^{a} & 210 & (0.23) & 0.23 \pm 0.03 & 0.0012 \\ 4 & 210 & 0.25-0.79 & 0.52 \pm 0.04 & 0.0026 \\ 5 & 210 & 0.06-0.43 & 0.24 \pm 0.03 & 0.0012\end{array}$

an1y one composite.

${ }^{b}$ Minimum Detection Limit (MDL) for ${ }^{238} \mathrm{Pu}$ in water is $0.01 \times 10^{-10}$ $\mu \mathrm{Ci} / \mathrm{ml}$ which is $0.00005 \%$ of the RCG.

${ }^{c}$ Radioactivity. Concentration Guide $(R C G)=20,000 \times 10^{-10} \mu \mathrm{Ci} / \mathrm{m} 1$ for the general population and the soluble form of plutonium-238.

${ }^{d}$ Error 1imits are counting statistics on $1 \mathrm{y}$ at $95 \%$ C.L.

Table 7

CONCENTRATION OF TRITIUM IN

THE GREAT MIAMI RIVER IN 1975

Number of

1.210

$2 \quad 210$

3210

4210

$5 \quad 210$

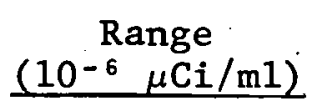

$<0.5-7.7$

$<0.5-17.5$

$<0.5-13.9$

$<0.5-19.8$

$<0.5-14.5$
Average a,c $\left(10^{-6} \mu \mathrm{Ci} / \mathrm{ml}\right)$

$<1.5 \pm 0.19$

$<2.1 \pm 0.23$

$<1.9 \pm 0.22$

$<2.1 \pm 0.23$

$\leqslant 1.7 \pm 0.20$
Percent of $\mathrm{RCG}^{\mathrm{b}}$

$<0.15$

$<0.21$

$<0.19$

$<0.21$

$<0.17$

ainimum Detection Limit (MDL) for tritium in water is $0.5 \times 10^{-6}$ $\mu \mathrm{Ci} / \mathrm{m} 1$ which is $0.05 \%$ of the RCG.

${ }^{b}$ Radioactivity Concentration Guide (RCG) $=1000 \times 10^{-6} \mu \mathrm{Ci} / \mathrm{m} 1$ for

' the general population and the soluble form of tritium.

${ }^{c}$ Error limits are counting statistics on 1 y at $95 \%$ C.L. 
Table 8

\title{
CONCENTRATION OF ${ }^{238} \mathrm{Pu}$ IN \\ CANAL/POND AREA IN 1975
}

\author{
Number of \\ $\left(10^{-10^{\text {Range }}} \mu \mathrm{Ci} / \mathrm{m} 1\right)$ \\ Average ${ }^{b, d}$ \\ Percent \\ Location $^{\text {a }}$ \\ Samples \\ $\left(10^{-10} \mu \mathrm{Ci} / \mathrm{ml}\right)$ \\ of $\mathrm{RCG}^{\mathrm{c}}$ \\ 6 (North Pond) \\ 210 \\ $0.63-3.8$ \\ $2.2 \pm 0.08$ \\ 0.01 \\ 210 \\ $0.83-5.9$ \\ $8.1-19.9$ \\ $3.4 \pm 0.10$ \\ $14.0 \pm 0.20$ \\ 0.02 \\ 210 \\ $8.1-19.9$ \\ 0.07 \\ ${ }^{a}$ Locations are shown in Figure 3 . \\ ${ }^{\mathrm{b}}$ Minimum Detection Limit (MDL) for ${ }^{238} \mathrm{Pu}$ in water is $0.01 \times 10^{-10}$. \\ $\mu \mathrm{Ci} / \mathrm{ml}$ which is $0.00005 \%$ of the RCG. \\ ${ }^{\circ}$ Radioactivity Concentration Guide $(\mathrm{RCG})=20,000 \times 10^{-10} \mu \mathrm{Ci} / \mathrm{m} 1$ \\ for the general population and soluble form of plutonium-238. \\ ${ }^{d}$ Error limits are counting statistics only at $95 \%$ C.L.
}

Table 9

CONCENTRATION OF TRITIIUM IN

CANAL/POND AREA IN 1975

\begin{tabular}{|c|c|c|c|c|}
\hline Location $^{2}$ & $\begin{array}{l}\text { Number of } \\
\text { Samples } \\
\end{array}$ & $\begin{array}{c}\text { Range } \\
\left(10^{-6} \mu \mathrm{Ci} / \mathrm{m} 1\right)\end{array}$ & $\begin{array}{c}\text { Average }{ }^{b, d} \\
\left(10^{-6} \mu \mathrm{Ci} / \mathrm{m} 1\right)\end{array}$ & $\begin{array}{l}\text { Percent } \\
\text { of } R C G \text {. }\end{array}$ \\
\hline $\begin{array}{l}6 \text { (North Pond) } \\
7 \text { (North Canal) } \\
8 \text { (South Canal) }\end{array}$ & $\begin{array}{l}210 \\
210 \\
210\end{array}$ & $\begin{array}{l}19-72 \\
18-87 \\
17-96\end{array}$ & $\begin{array}{l}37 \pm 1.0 \\
39 \pm 1.0 \\
43 \pm 1.0\end{array}$ & $\begin{array}{l}3.7 \\
3.9 \\
4.3\end{array}$ \\
\hline
\end{tabular}

"Locations are shown in Figure 3.

${ }^{b}$ Mimimum Detection Limit (MDL) for tritium in water is $0.5 \times 10^{-6}$. $\mu \mathrm{Ci} / \mathrm{ml}$ which is $0.05 \%$ of the RCG.

${ }^{c}$ Radioactivity Concentration Guide $(\mathrm{RCG})=1000 \times 10^{-6} \mu \mathrm{Ci} / \mathrm{ml}$ for the general population and soluble form of tritium.

${ }^{d}$ Error limits are counting statistics only at $95 \%$ C.L. 
readily seen by comparing plutonium-238 quantities found in the effluent streams with concentrations found off-site.

Eight additional surface water locations such as ponds are sampled annually. These samples, used for plutonium-238 determination, are large volume water samples of approximately 40 liters each. The large volume of sample increases the sensitivity of the analysis. A smaller aliquot $(10 \mathrm{~m} 1)$ was taken for the tritium oxide analysis. The average concentrations of plutonium-238 and tritium oxide at these locations were $0.65 \times 10^{-10} \mu \mathrm{Ci} / \mathrm{ml}$ and $<1.2 \times 10^{-6} \mu \mathrm{Ci} / \mathrm{ml}$, respectively, which are $0.003 \%$ and $0.12 \%$ of their respective RCG's for the general population. The results of the surface water monitoring program are summarized in Tables 10 and 11 .

Table 10

SUMMARY OF SURFACE ' WATER MONITORING FOR PLUTONIUM-238 IN 1975

\begin{tabular}{cccc} 
Location & $\begin{array}{c}\text { Number of } \\
\text { Samples }\end{array}$ & $\begin{array}{c}\text { Average } \\
\left(10^{-10} \mu \mathrm{Ci} / \mathrm{m} 1\right)\end{array}$ & $\begin{array}{c}\text { Percent } \\
\text { of RCG }\end{array}$ \\
\cline { 2 - 3 } & 1 & $1.4 \pm 0.02$ & 0.007 \\
11 & 1 & $1.5 \pm 0.02$ & 0.008 \\
12 & 1 & $0.67 \pm 0.02$ & 0.003 \\
13 & 1 & $0.34 \pm 0.01$ & 0.002 \\
14 & 1 & $0.41 \pm 0.01$ & 0.002 \\
15 & 1 & $0.66 \pm 0.02$ & 0.003 \\
16 & 1 & $0.09 \pm 0.01$ & 0.0006 \\
17 & 1 & $0.14 \pm 0.01$ & 0.0007
\end{tabular}

Minimum Detection Limit (MDL) for ${ }^{238} \mathrm{Pu}$ in water is $0.003 \times 10^{-10} \mu \mathrm{Ci} / \mathrm{ml}$. The MDL $=0.000015 \%$ of the RCG.

"Radioactivity Concentration Guide (RCG) for ${ }^{2{ }^{3}} \mathrm{Pu}$ in water $=20,000 \times 10^{-10} \mu \mathrm{Ci} / \mathrm{m} 1$ for the general population and soluble form of plutonium-238.

${ }^{c}$ Error limits are counting statistics only at $95 \%$ C.L.

In addition, background levels of plutonium-238 and tritium oxide for surface water are shown in Table 3 .

Drinking water from communities in the surrounding area is sampled and analyzed semiannually for tritium oxide with the exception of drinking water from Miamisburg which was sampled and analyzed monthly for tritium oxide. These communities are shown in Figure 1. 
Table 11

SUMMARY OF SURFACE WATER MONITORING

FOR TRITIUM IN 1975

\begin{tabular}{cccc} 
Location & $\begin{array}{c}\text { Number of } \\
\text { Samples }\end{array}$ & $\begin{array}{c}\text { Average } \\
\left(10^{-6} \mu \mathrm{Ci} / \mathrm{m} 1\right)\end{array}$ & $\begin{array}{r}\text { Percent } \\
\text { of RCG }\end{array}$ \\
\cline { 2 - 3 } 10 & 1 & $0.9 \pm 0.1$ & 0.09 \\
11 & 1 & $3.1 \pm 0.2$ & 0.31 \\
12 & 1 & $<0.3 \pm 0.1$ & $<0.03$ \\
13 & 1 & $0.8 \pm 0.1$ & 0.08 \\
14 & 1 & $1.5 \pm 0.1$ & 0.15 \\
15 & 1 & $0.6 \pm 0.1$ & 0.06 \\
16 & 1 & $0.4 \pm 0.1$ & 0.04 \\
17 & 1 & $2.1 \pm 0.2$ & 0.21
\end{tabular}

${ }^{a}$ Minimum Detection Limit (MDL) for tritium in water is $0.3 \times 10^{-6} \mu \mathrm{Ci} / \mathrm{ml}$. The MDL is $0.03 \%$ of the RCG.

${ }^{b}$ Radioactivity Concentration Guide (RCG) for tritium oxide in water $=.1000 \times 10^{-6} \mu \mathrm{Ci} / \mathrm{m} 1$ for the general population and soluble form of tritium.

${ }^{c}$ Error limits are counting statistics only at $95 \%$ C.L.

The average concentration of tritium oxide was $<1.4 \times 10^{-6} \mu \mathrm{Ci} / \mathrm{ml}$ which is $<0.14 \%$ of the RCG for the general population. The results of the community drinking water sampling program are summarized in Table 12 .

Several private wells in the vicinity of Mound Laboratory were also sampled and analyzed monthly for tritium oxide. The average concentration of tritium oxide in these we1ls was $50.0 \times 10^{-6} \mu \mathrm{Ci} / \mathrm{ml}$ which is $5.0 \%$ of the RCG for the general population. The we 11 results are summarized in Table 13. : These wells apparently have been minutely. influenced by Mound Laboratory tritium effluent releases in water. As shown by the data, concentrations in these wells are higher than in other wells in the area, but much less than the RCG. This situation has apparently developed from years of releasing quantities of water effluents at a small fraction of the RCG. Part of this water effluent has migrated into the aquifer at short distances from Mound Laboratory.

Two private wells and Miamisburg city water were sampled and analyzed month1y for plutonium-238. These samples also were large volume water samples averaging 40 liters. The average plutonium-238 concentration of these samples was $0.06 \times 10^{-10} \mu \mathrm{Ci} / \mathrm{m} 1$ which is $0.0003 \%$ of the RCG for the general population. These results are shown in Table 14 . 
Table 12

\section{SUMMARY OF TRITIUM OXIDE LEVEIS \\ IN COMMUNITY DRINKING WATER IN 1975}

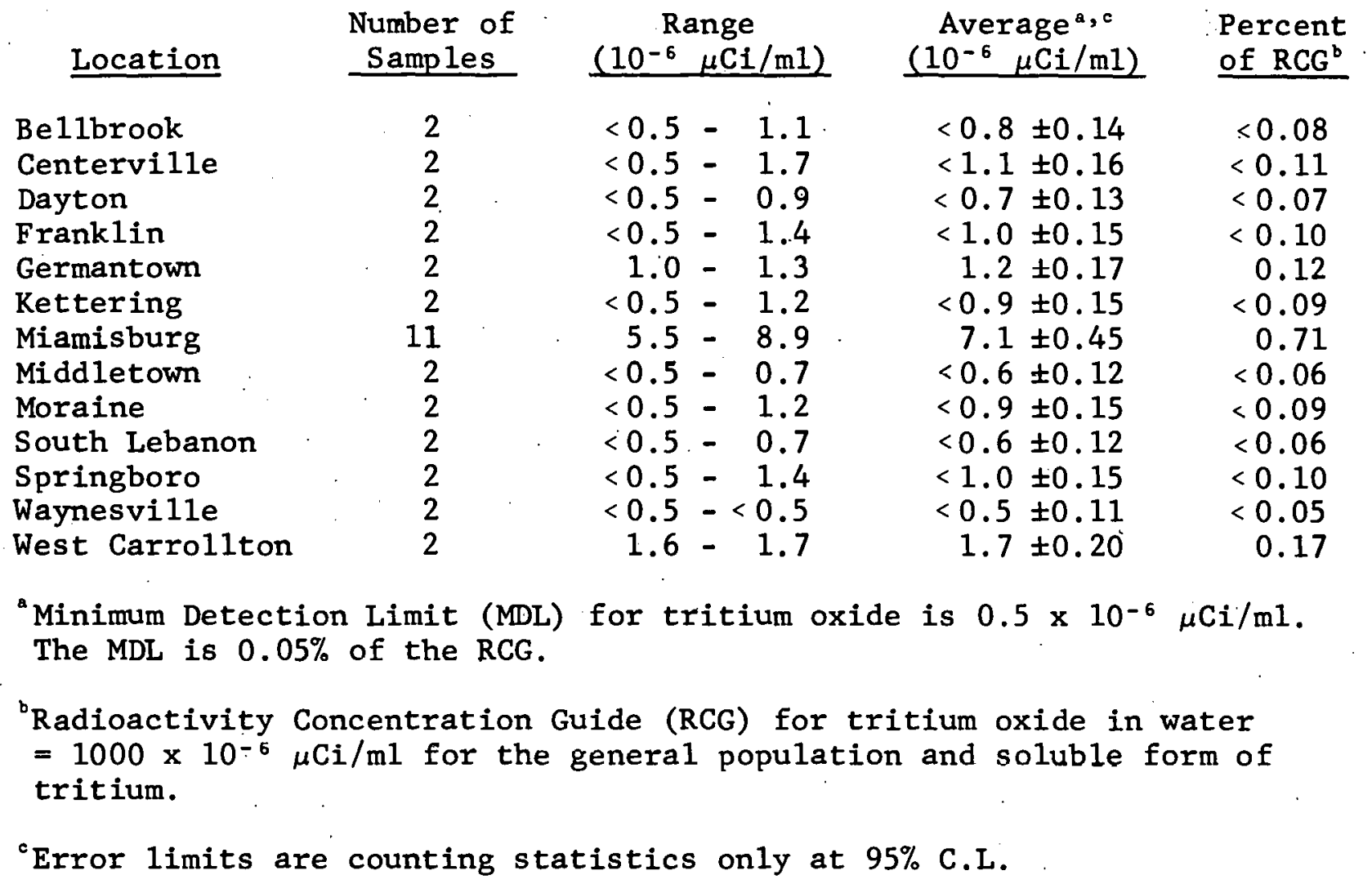

Table 13

TRITIUM-OXIDE IN PRIVATE WELLS IN 1975

\begin{tabular}{lccccc} 
Location & $\begin{array}{c}\text { Number of } \\
\text { Samples }\end{array}$ & $\begin{array}{c}\text { Range } \\
\left(10^{-6} \mu \mathrm{Ci} / \mathrm{m} 1\right)\end{array}$ & $\begin{array}{c}\text { Average } \mathrm{a}, \mathrm{c} \\
\left(10^{-6} \mu \mathrm{Ci} / \mathrm{m} 1\right)\end{array}$ & $\begin{array}{c}\text { Percent } \\
\text { of } \mathrm{RCG}^{\mathrm{b}}\end{array}$ \\
\cline { 2 - 2 } $\mathrm{B}-1$ & 11 & & $65.3-89.9$ & $74.9 \pm 1.5$ & 7.5 \\
$\mathrm{~B}-2$ & 11 & $32.7-40.0$ & $35.7 \pm 1.0$ & 3.6 \\
$\mathrm{~B}-3$ & 11 & $34.6-42.9$ & $37.7 \pm 1.0$ & 3.8 \\
$\mathrm{~J}-1$ & 11 & $44.0-63.5$ & $51.5 \pm 1.2$ & 5.2
\end{tabular}

ainimum Detection Lim1t (MDL) for tritium oxide i.s $0.6 \times 10^{-6} \mu \mathrm{Ci} / \mathrm{m} 1$. The MDL is $0.06 \%$ of the RCG.

${ }^{b}$ Radioactivity Concentration Guide (RCG) for tritium oxide in water $=1000 \times 10^{-6} \mu \mathrm{Ci} / \mathrm{ml}$ for general population and soluble form of tritium.

${ }^{c}$ Error 1imits are counting statistics only at $95 \%$ C.I. 
Table 14

PLUTONIUM-238 IN PRIVATE WELLS AND
MIAMISBURG MUNICIPAL DRINKING WATER IN 1975

\begin{tabular}{|c|c|c|c|c|}
\hline Location & $\begin{array}{c}\text { Number of } \\
\text { Samples }\end{array}$ & $\begin{array}{l}\text { Range } \\
\left(10^{-10} \mu \mathrm{Ci} / \mathrm{ml}\right)\end{array}$ & $\begin{array}{c}\text { Average }{ }^{a, c} \\
\left(10^{-10} \mu \mathrm{C} i / \mathrm{m} 1\right)\end{array}$ & $\begin{array}{l}\text { Percent } \\
\text { of } \mathrm{RCG}^{\mathrm{b}}\end{array}$ \\
\hline Miamist & 11 & $0.07-0.80$ & $0.43 \pm 0.03$ & 0.002 \\
\hline $\mathrm{J}$ & 11 & $0.08-0.33$ & $0.20 \pm 0.02$ & 0.001 \\
\hline B & 11 & $0.04-0.08$ & $0.06 \pm 0.01$ & 0.0003 \\
\hline
\end{tabular}

${ }^{a}$ Minimum Detection Limit (MDL) for ${ }^{238} \mathrm{Pu}$ is $0.006 \times 10^{-10} \mu \mathrm{Ci} / \mathrm{m} 1$. The MDL is $0.00003 \%$ of the RCG.

${ }^{b}$ Radioactivity Concentration Guide (RCG) for ${ }^{238} \mathrm{Pu}$ in water $=20,000 \times 10^{-10} \mu \mathrm{Ci} / \mathrm{m} 1$ for the general population and soluble form of plutonium-238.

${ }^{c}$ Error limits are counting statistics only at $95 \%$ C.L.

WATER - NONRADIOACTIVE

Mound Laboratory was issued a discharge permit under the National Pollutant Discharge Elimination System (NPDES). The permit was issued by Region V of the USEPA effective July 1, 1975. Each of the two effluent streams from Mound which discharge to the Great Miami River has limitations specified by the discharge permit. The discharge from outfal1 number 001 includes the discharge from the sanitary waste treatment plant, radioactive waste disposal facility, single-pass cooling water, zeolite softener backwash, and some storm water runoff. The discharge from outfall number 002 consists of single-pass cooling water, cooling-tower blowdown, boiler-plant blowdown, zeolite softener backwash, and most of the storm water runoff. A 24-hr composite sample of each effluent stream is automatically collected daily. The volume of samples collected is proportional to the flow in the stream. The composite. effluent water samples are analyzed for the water quality parameters listed in Tables 10 and 11 according to standard methods. ${ }^{10}$ The results of effluent stream analyses for 1975 are summarized in Tables 15 and 16 . A11 results are within permit limitations with the exception of oil and grease. The limitation was exceeded once for outfall 001 and twice for outfa11 002 . A contaminated sample or an analytical error is suspected since no discharge of oil, either intentional or accidental, was reported or observed. However, since the flow of the Great Miami River, even under low-flow conditions, was approximately 400 times the maximum flow discharge from Mound during $1975^{11}$, these limitation exceptions had no significant effect on the River and certainly did not cause the Ohio Stream Standards to be exceeded. 
Table 15

1975 NATIONAL POLLUTANT DISCHARGE ELIMINATION SYSTEM PERMIT DATA FOR STATION 001

\begin{tabular}{|c|c|c|c|c|c|}
\hline Parameter & & No. Samples & Minimum & Maximum & Average \\
\hline Flow & $\begin{array}{l}\text { Reported } \\
\text { Permit }\end{array}$ & Cont. & 0.12 MGD & $\begin{array}{l}0.33 \text { MGD } \\
0.92\end{array}$ & $\begin{array}{l}0.19 \text { MGD } \\
0.53\end{array}$ \\
\hline $\mathrm{BOD}_{5}$ & $\begin{array}{l}\text { Reported } \\
\text { Permit }\end{array}$ & 52 & 3.2 & $\begin{array}{l}23.6 \\
45.0\end{array}$ & $\begin{array}{r}8.9 \\
30.0\end{array}$ \\
\hline $\begin{array}{l}\text { Fecal } \\
\text { Coliform }\end{array}$ & $\begin{array}{l}\text { Reported } \\
\text { Permit }\end{array}$ & 26 & ND & $\begin{array}{r}15.0 \\
400.0\end{array}$ & $\begin{array}{r}5.4 \\
200.0\end{array}$ \\
\hline $\begin{array}{l}\text { Suspended } \\
\text { Solids }\end{array}$ & $\begin{array}{l}\text { Reported } \\
\text { Permit }\end{array}$ & 52 & ND & $\begin{array}{l}44.0 \\
45.0\end{array}$ & $\begin{array}{l}16.9 \\
30.0\end{array}$ \\
\hline $\begin{array}{l}\text { Dissolved } \\
\text { Oxygen }\end{array}$ & $\begin{array}{l}\text { Reported } \\
\text { Permit }\end{array}$ & 182 & 5.4 & 9.6 & $\begin{array}{l}7.4 \\
5.0\end{array}$ \\
\hline $\begin{array}{l}\text { Residual } \\
\text { Chlorine }\end{array}$ & $\begin{array}{l}\text { Reported } \\
\text { Permit }\end{array}$ & 52 & 0.25 & $\begin{array}{l}0.8 \\
0.8\end{array}$ & 0.61 \\
\hline $\begin{array}{l}\text { Oil and } \\
\text { Grease }\end{array}$ & $\begin{array}{l}\text { Reported } \\
\text { Permit }\end{array}$ & 26 & ND & $\begin{array}{l}22.3 \\
10.0\end{array}$ & 2.7 \\
\hline $\mathrm{pH}$ & $\begin{array}{l}\text { Reported } \\
\text { Permit }\end{array}$ & 182 & $\begin{array}{l}6.2 \\
6.0\end{array}$ & $\begin{array}{l}8.3 \\
9.0\end{array}$ & \\
\hline Carbon & $\begin{array}{l}\text { Reported } \\
\text { Permit }\end{array}$ & 52 & $\begin{array}{c}53.0 \\
-\end{array}$ & $\begin{array}{c}110.0 \\
-\end{array}$ & $\begin{array}{l}85.0 \\
-\end{array}$ \\
\hline Ammonia & $\begin{array}{l}\text { Reported } \\
\text { Permit }\end{array}$ & 26 & $\begin{array}{c}0.1 \\
-\end{array}$ & $\begin{array}{l}0.1 \\
-\end{array}$ & $\begin{array}{l}0.1 \\
-\end{array}$ \\
\hline
\end{tabular}

NOTES :

ND - none detectable.

MGD - million gallons per day.

Values for fecal coliform are number of coliform per $100 \mathrm{~m} 1$ of water. All other values are in milligrams per liter.

\section{FOODSTUFFS AND VEGETATION - RADIOACTIVE}

Various locally grown foodstuffs and vegetation samples are collected from the surrounding area. The intent of this portion of the Environmental Monitoring Program is to determine whether there is any uptake and concentration of radionuclides by plant or animal life. Where possible, sampling sites are chosen at maximum deposition locations predicted on the basis of the diffusion model developed for Mound Laboratory. Ficld crops, fruit, and vegetables are collected on the 
Table 16

1975 NATIONAL POLLUTANT DISCHARGE ELIMINATION SYSTEM PERMIT DATA FOR STATION 002

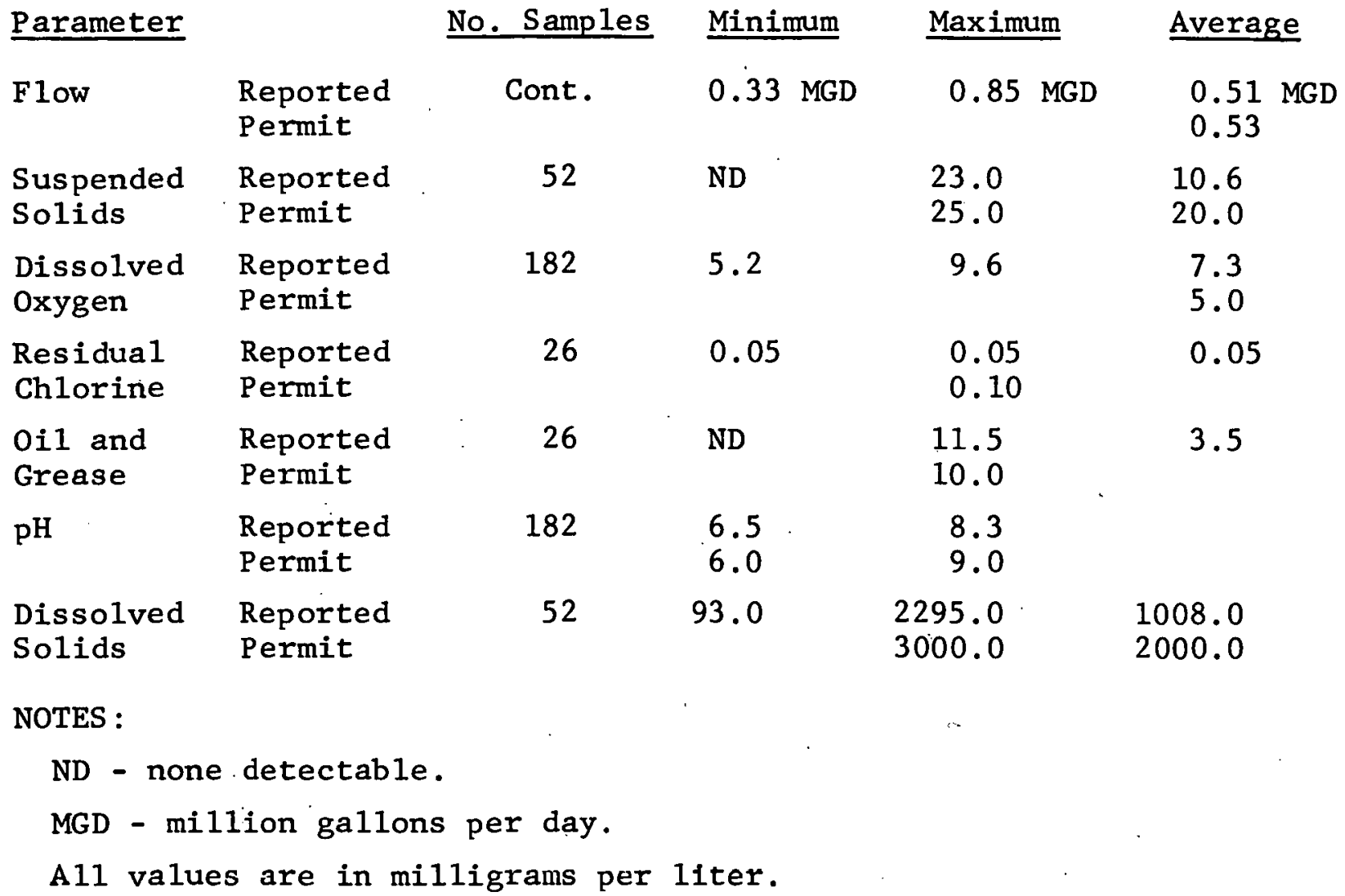

basis of this diffusion model. Milk is collected from individual farms closest to the Laboratory. Aquatic life is trapped from the Miami River generally downstream of Miamisburg and from adjacent waterways, dependent upon availability of fish. Grass samples are collected in the vicinity of the surface water locations listed in Tables 17 and 18. The plutonium-238 content of the foodstuff and vegetation samples is determined by slowly evaporating the samples to dryness and then proceeding with the same techniques used. for plutonium-238 analyses of air samples (see section on Air - Radioactive). Milk samples are analyzed for tritium oxide by distilling the water fraction from an aliquot. The distillate is then analyzed for tritium by liquid scintillation spectrometry in the same manner as the water samples previously discussed in this report (see section on Water - Radioactive). The remaining foodstuff samples are analyzed for tritium by oxidizing the samples in a controlled air stream and collecting the combustion products. The tritium content of the combustion products is then determined by liquid scintillation spectrometry as discussed above. This technique allows analysis for total tritium in the samples rather than tritium oxide 
only. The results of the foodstuff and vegetation analyses are summarized in Table 17 and 18. The concentration is given in terms of the sample weight (wet weight) before evaporation to dryness. The vegetables and fruits analyzed included potatoes and tomatoes. The field crops analyzed were the edible portions of corn and soybeans. The sample of aquatic life analyzed included only the edible fleshy portions of the fish. No evidence has been found that there is any significant uptake and concentration by plant or animal life of the radionuclides handled at Mound Laboratory.

Table 17

PLUTONIUM-238 IN FOODSTUFFS

AND VEGETATION IN 1975

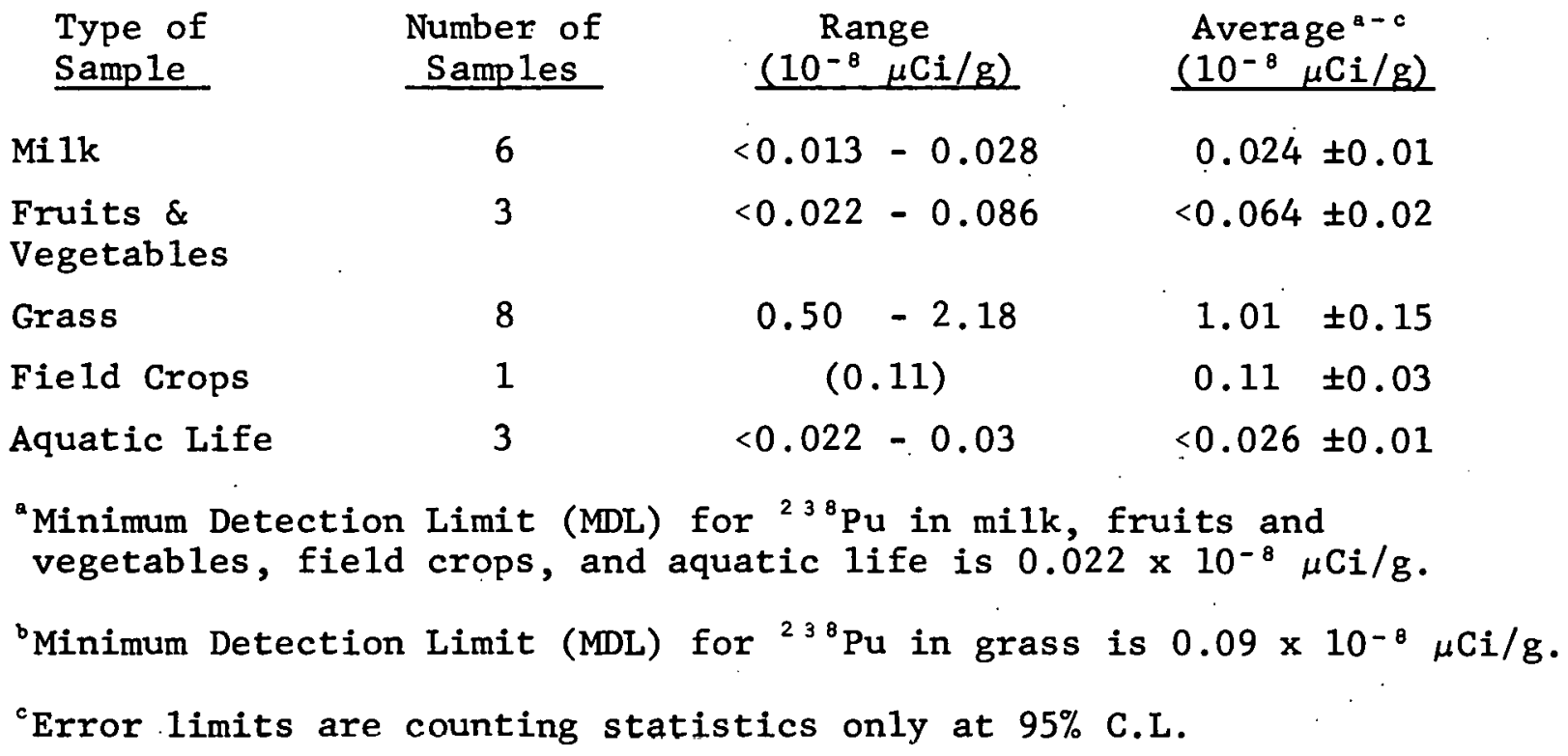

SOIL AND SILT - RADIOACTIVE

During CY-1975 emphasis was placed on the evaluation of previously collected soil monitoring data, specifically soil core samples. The program is twofold, evaluation of plutonium-238 deposition from releases via water and evaluation of plutonium-238 deposition from releases via stack.

Preliminary soil and silt samples collected from off-site sediment in the Miami-Erie canal area near Mound Laboratory indicated that plutonium-238 concentrations were substantially above baseline levels. As a result, an extensive sampling and analysis program was performed during 1974 to determine plutonium-238 concentrations as a function of depth and location in the drainage ditch, the canal, two ponds, a runoff hollow, a canal overflow creek, and the Great Miami River. The study 
Table 18

TRITIUM IN FOODSTUFFS

AND VEGETATION IN 1975

Type of

Sample

Mi 1k

Fruits \&

Vegetables

Grass

Field Crops

Aquatic Life
Number of

Samples

3

1

8

1

3
Average a,b

$\left(10^{-6} \mu \mathrm{Ci} / \mathrm{g}\right)$

$<10.5 \pm 6.9$

$<4.4 \pm 2.9$

$<4.4 \pm 2.9$

$<4.9 \pm 3.3$

$<4.4 \pm 2.9$

A11 samples less than Minimum Detection Limit (MDL). MDL for tritium in fruits and vegetables, grass, and aquatic life $=4.4 \times 10^{-6} \mu \mathrm{Ci} / \mathrm{g}$. MDL for tritium in field crops $=4.9 \times 10^{-6} \mu \mathrm{Ci} / \mathrm{g}$. MDL for tritium in $\operatorname{milk}=10.5 \times 10^{-6} \mu \mathrm{Ci} / \mathrm{g}$.

${ }^{b}$ Error 1imits are counting statistics on 1 y at $95 \%$ C.L.

found that in January, 1969, plutonium-238 had been released when an underground pipeline carrying plutonium-238 waste solution from the Plutonium Processing ( $P P$ ) Building to the Waste Disposal (WD) Facility ruptured. Acidic waste solution containing plutonium-238 was released to the soil adjacent to the pipe. The plutonium was quickly and strongly sorbed by the soil where it was immobilized. During excavation and repair operations in 1969 when the contaminated soil was most susceptible to erosion, the weather warmed and there was intense rainfall for two days. This heavy rain eroded the exposed surface of the contaminated soil causing the soil particles to be carried off-site. These erosion products, suspended in the moving water, settled according to normal sedimentation processes in the waterways adjacent to Mound Laboratory. From 1974 sampling and analysis data, it was determined that about $5.2 \mathrm{Ci}$ of plutonium-238 were deposited on sediment in these waterways, approximately $1-1 / 2$ miles 1 ong, mostly buried under up to $3 \mathrm{ft}$ of sediment. ${ }^{5}$.

Soil core sample values around and within the Laboratory site boundary were used to arrive at a preliminary estimate of deposition of airborne plutonium-238 from Laboratory operations. It should be pointed out that this is not a final estimate of the inventory value. More core samples should be taken in order to obtain a statistically valid inventory value. A minimum of 80 additional sampling locations is planned. 
The preliminary soil inventory was established within the $1 \mathrm{mCi} / \mathrm{km}^{2}$. boundary of plutonium-238 concentrations. Additional data, to be collected during 1976 , will be required to assess the inventory beyond the $1 \mathrm{mCi} / \mathrm{km}^{2}$ boundary.

The concentrations were determined by using a planimeter on an enlarged map of the area (see Figure 4). Iso-millicurie lines were determined from soil samples taken in and around the Laboratory vicinity. The area between each isopleth was measured by the planimeter. The millicurie concentration between each contour line was calculated by taking the product of the area and the average value of the two boundary contour lines.

Equations were developed for each of 16 directions from Mound Laboratory of the form: $y=a x^{b}$

$$
\text { where } \begin{aligned}
\mathrm{y} & =\text { concentration } \\
\mathrm{a} & =\text { constant } \\
\mathrm{x} & =\text { distance } \\
\mathrm{b} & =\text { exponent }
\end{aligned}
$$

These equations were used to plot additional isopleths to fill gaps in the data where no soil core samples had been taken. These additional contours were then used to determine a revised estimate of the total millicurie value in the vicinity of Mound Laboratory.

The estimate of deposited plutonium-238 is $464 \mathrm{mCi}$ outside Mound Laboratory within the $1 \mathrm{mCi} / \mathrm{km}^{2}$ boundary. It should be pointed out again that this estimate is only a preliminary estimate. More core sampling data are needed to arrive at a final estimate.

In summary, a preliminary evaluation indicates that airborne releases of plutonium-238 have contributed roughly $0.5 \mathrm{Ci}$ to the off-site environment as deposition on soil. Water releases of plutonium-238 are responsible for an additional $5.2 \mathrm{Ci}$ deposited in the off-site adjacent waterways. 


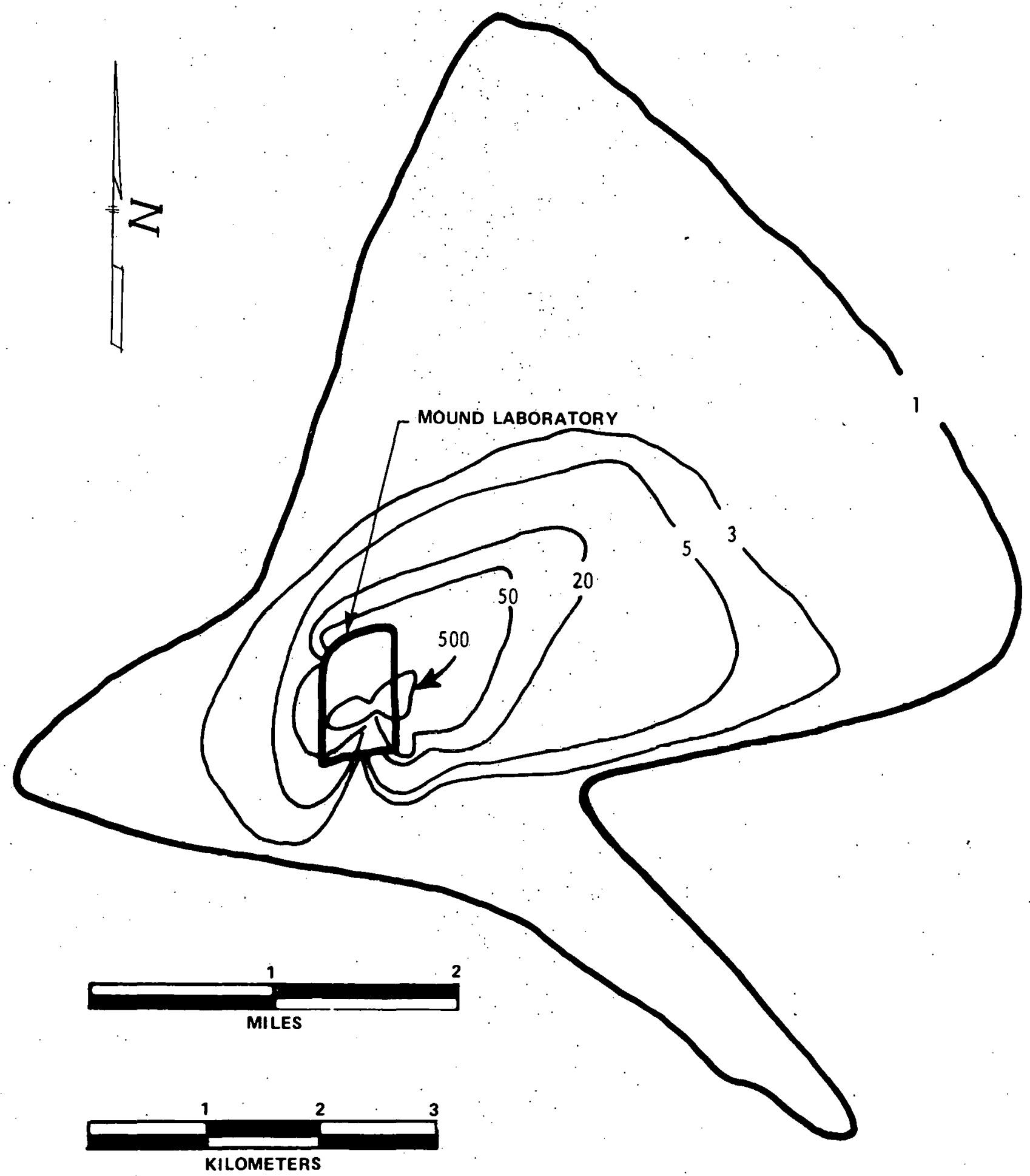

FIGURE 4 - Millicurie per square kilometer isopleths 


\section{Evaluation of Potential Dose to the Public}

A dose assessment was performed for each radionuclide measureable in the environment from Mound Laboratory operations. These radionuclides are plutonium-238 and tritium. Tritium (oxide) is the only radionuclide at Mound Laboratory for which the critical organ is the whole body. The critical organs for plutonium-238 are assumed to be the lung for insoluble material and the bone for soluble material since the solubility in the receptor is unknown. In order to resolve the uncertainty of the solubility of plutonium, each dose evaluation for the lung or the bone included $100 \%$ of the concentration found in the environment, which gives a very conservative estimate.

\section{PLUTONIUM-238}

Assumptions and Methodology The dose estimates for plutonium-238 were based on environmental monitoring data for CY-1975. The estimates for maximum dose to the lung at the site boundary and maximum dose to the lung in individuals were based on the maximum on-site average concentration of plutonium-238 in air from our on-site samplers since the samplers are in close proximity to the site boundary. The maximum dose to the lung in population group(s) was based on the maximum off-site average concentration of plutonium-238 in air.

The estimates for maximum dose to the bone at the site boundary and in individuals were also based on the maximum on-site average concentration of plutonium-238 in air and the maximum off-site average concentration of plutonium-238 in drinking water. The maximum dose to the bone for population group(s) was based on the maximum off-site average concentration of plutonium-238 in air and water. The total dose equivalent for bone was obtained by the addition of the dose equivalent of plutonium in air and the dose equivalent of plutonium in water.

Calculational Methods The dose equivalent to the lung resulting from continuous inhalation of airborne plutonium-238 was calculated by:

$$
D(t)=\frac{51.1 .1 I_{a} t f_{a} f_{r} \sum E F(R B E) x}{\lambda m}\left(1-\frac{1-e^{-\lambda t}}{\lambda t}\right)
$$

where $D(t)=$ dose equivalent delivered to the lung in 365 days of continuous exposure to plutonium-238 in air, rem/yr 


$$
\begin{aligned}
& \mathrm{C}=\text { average airborne concentration, } \mu \mathrm{Cl} / \mathrm{ml} \\
& I_{a}=\text { average air intake }=2 \times 10^{7} \mathrm{ml} / \text { day (Ref. 17) } \\
& t=\text { time exposed, } 365 \text { days } \\
& f_{a}=\text { fraction of inhaled material reaching organ of interest } \\
& =0.7 \text { (max.) for the pulmonary region (Ref. 22) } \\
& f_{r}=\text { fraction of pulmonary deposition undergoing long-term } \\
& \text { retention }=0.6 \text { for actinide (class } \mathrm{Y} \text { ) (Ref. 22) } \\
& \Sigma E F(R B E) x=\text { effective energy deposition per disintegration }=57 \text {. } \\
& \lambda \text { = effective decay rate, } 0.0014 \text { day }^{-1} \text { for actinides } \\
& \text { (class Y) from the pulmonary region (Ref. 23) } \\
& \mathrm{m}=\text { lung mass, } 1000 \mathrm{~g} \text { (Ref. 17) }
\end{aligned}
$$

The dose equivalent to bone resulting from continuous inhalation of airborne plutonium-238 was calculated by:

$$
\begin{aligned}
& D(t)=\frac{51.1 C I_{a} f_{a} t \operatorname{EEF}(\mathrm{RBE}) x}{\lambda m}\left(1-\frac{1-e^{-\lambda t}}{\lambda t}\right) \\
& \text { where } f_{a}=0.2(\operatorname{Ref} .17) \\
& \Sigma E F(\operatorname{RBE}) x=284 \text { (Ref. 17) } \\
& \dot{\mathrm{m}}=7 \times 10^{3} \mathrm{~g}(\operatorname{Ref} \cdot 17) \\
& \lambda=3 \times 10^{-5} \mathrm{day}^{-1}(\operatorname{Ref}, 17)
\end{aligned}
$$

The dose equivalent to bone resulting from continuous ingestion of plutionium-238 in water was calculated by:

$$
D(t)=\frac{51.1 C I_{k} f_{a} t \Sigma E F(R B E) x}{\lambda m}\left(1-\frac{1-e^{-\lambda t}}{\lambda t}\right)
$$

. where $\cdot I_{N}=$ average quantity of water intake, $2200 \mathrm{~cm}^{3}$ (Ref. 17)

$$
f_{a}=2.4 \times 10^{-5}(\operatorname{Ref} \cdot 17)
$$

The results of the calculations are:

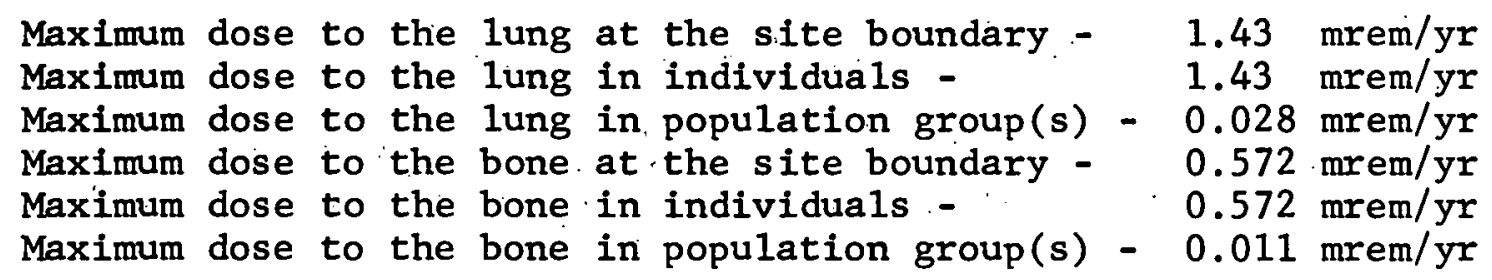


Assumptions and Methodology The dose estimates for tritium (oxide) were also based on environmental monitoring data for $\mathrm{CY}-1975$. The concentrations used for dose estimates for tritium (oxide) were produced by the same method as that used for plutonium. The total dose equivalent for the whole body was obtained by addition of the dose equivalent of tritium (oxide) in air and the dose equivalent of tritium (oxide) in air and the dose equivalent of tritium (oxide) in water.

Calculational Methods The dose equivalent to the whole body resulting from continuous exposure to tritium (oxide) in air was calculated by:

$$
D(t)_{a}=\frac{\bar{C}_{a}}{R_{a}} \times S
$$

where $D(t)_{a}=$ dose equivalent, mrem/yr

$$
\begin{aligned}
\vec{C}_{\mathrm{a}} & =\text { average concentration of tritium (oxide) in air } \\
\mathrm{R}_{\mathrm{a}} & =\mathrm{RCG} \text { for tritium (oxide) in air (Ref. 8) } \\
\mathrm{S} & =\text { Radiation protection standard in mrem/yr (Ref. 8) }
\end{aligned}
$$

- The dose equivalent to the whole body resulting from continuous uptake of tritium (oxide) in water was calculated by:

$$
\begin{aligned}
D(t)_{w}=\frac{\bar{C}_{w}}{R_{w}} \times S & \\
\text { where } D(t)_{w} & =\text { dose equivalent in mrem/yr } \\
\bar{C}_{w} & =\text { average concentration } \\
R_{w} & =\text { RCG for tritium (oxide) in water (Ref. 8) } \\
S & =\text { radiation protection standard in mrem/yr (Ref. 8) }
\end{aligned}
$$

These dose equivalent values were divided by 1.7 in order to reflect the quality factor of one as recommended by the International Commission on Radiological Protection ${ }^{18}$ and the National Council on Radiation Protection and Measurements..$^{19}$

The results of the calculations are:

Maximum dose at the site boundary - $\quad 4.84 \mathrm{mrem} / \mathrm{yr}$

Maximum dose to an Individual - $\quad 4.84 \mathrm{mrem} / \mathrm{yr}$

Maximum dose to population group(s) - $4.81 \mathrm{mrem} / \mathrm{yr}$ 
The 50-mi $(80-\mathrm{km})$ person-rem (whole body) dose estimates were based on average tritium (oxide) data from environmental air sampling stations, average tritium (oxide) data in community drinking water, and atmospheric dispersion estimates.

Two ranges of dose estimates were considered to obtain the $50-\mathrm{mi}(80-\mathrm{km})$ person-rem dose estimate. The first range was from 0 to $2 \mathrm{mi}(3.2 \mathrm{~km})$. The second range was from 2 to $50 \mathrm{mi}$. This distance breakdown was used because of the placement of samplers in the Mound diffusion model.

The 0 to $2 \mathrm{mi}$ range dose estimate for airborne tritium oxide was obtained from the average concentration (less background) of seven offsite tritium (oxide) samplers within a 2 -mi radius of Mound Laboratory. This distance range dose from tritium (oxide) in water was obtained from a weighted average of drinking water concentrations. These dose equivalents from tritium (oxide) in air and in water were summed.

The equations used for this calculation were:

$$
\begin{aligned}
& \underset{0-2}{\bar{D}(t)_{a}}=\frac{\bar{C}_{a}}{R_{a}} \times S \\
& \text { where } \overline{\mathrm{D}}(\mathrm{t})_{a}=\text { dose equivalent from 0-2 mi from tritium (oxide) in air } \\
& \text { - } \overline{\mathrm{C}}_{\mathrm{a}}=\text { average tritium (oxide) concentration in air from } \\
& 0 \text { to } 2 \mathrm{mi} \\
& \mathrm{R}_{\mathrm{a}}=\mathrm{RCG} \text { for tritium (oxide) in air (Ref. 8) } \\
& S=\text { radiation protection standard for tritium (oxide) in } \\
& \text { air in } \mathrm{mrem} / \mathrm{yr}(\operatorname{Ref} .8) \\
& \underset{0-2}{\bar{D}(t)_{w}}=\frac{\overline{\mathrm{C}}_{w}}{\mathrm{R}_{w}} \times \mathrm{S} \\
& \begin{aligned}
\text { where } & \overline{\mathrm{D}}(\mathrm{t})_{\mathrm{N}}=\text { dose equivalent from } 0-2 \mathrm{mi} \text { from tritium (oxide) } \\
\text { in water } & \text {. }
\end{aligned} \\
& \overline{\mathrm{C}}_{w}=\text { average tritium (oxide) concentration in water } \\
& \text { from 0-2 mi } \\
& R_{W}=\text { RCG for tritium (oxide) in water (Ref. 8) } \\
& S \text { = radiation protection standard for tritium (oxide) } \\
& \text { in water, mrem/yr (Ref. 8) }
\end{aligned}
$$

The 2 to 50-mi range dose estimate was obtained by finding the midpoint distance where the average tritium (oxide) concentration of the remaining off-site samplers would be located. This value is estimated at 
$4.4 \mathrm{mi}^{20}$ From this distance and average concentrations of tritium (oxide) at sampling locations from 2 to $20 \mathrm{mi}$, it was determined that the maximum distance of influence from Mound Laboratory is $\sim 22 \mathrm{mi}$. Beyond $22 \mathrm{mi}$ the levels are calculated to be background concentrations.

The dose equivalent for tritium (oxide) from 2 to $22 \mathrm{mi}$ was based on the average of the remaining tritium (oxide) air sample concentrations and the average of the remaining community drinking water concentrations.

The equations for these calculations are:

$$
\begin{aligned}
& \underset{2-22}{\bar{D}}(t)_{a}=\frac{\bar{C}_{a}}{R_{a}} \times S \\
& \text { where } \underset{2-22}{\bar{D}}(t)_{a}=\text { dose equivalent from 2-22 mi from tritium (oxide) }_{\text {In alr }} \\
& \overline{\mathrm{C}}_{\mathrm{a}}=\text { average tritium (oxide) concentrations in air from } \\
& 2 \text { to } 22 \mathrm{mi} \\
& R_{a}=\text { RCG for tritium (oxide) in air (Ref. 17) } \\
& \mathrm{S}=\text { Radiation Protection Standard for tritium (oxide) } \\
& \text { in air, mrem/yr (Ref. 17) } \\
& \underset{2-22}{\bar{D}}(t)_{w}=\frac{\bar{C}_{w}}{R_{w}} \times S \\
& \text { where } \underset{2-22}{\bar{D}(t)_{w}}=\begin{array}{l}
\text { dose equivalent from } 2-22 \mathrm{mi} \text { from tritium (oxide) } \\
\text { in water }
\end{array} \\
& \overline{\mathrm{C}}_{\mathrm{w}}=\text { average tritium (oxide) concentration in water } \\
& \text { from } 2 \text { to } 22 \mathrm{mi} \\
& R_{w}=\text { RCG for tritium (oxide) in water (Ref, 17) } \\
& \mathrm{S} \text { = Radiation Protection Standard for tritium (oxide) } \\
& \text { in water, mrem/yr (Ref. 17) }
\end{aligned}
$$

The total person-rem from $0-22 \mathrm{mi}$ is obtained by:

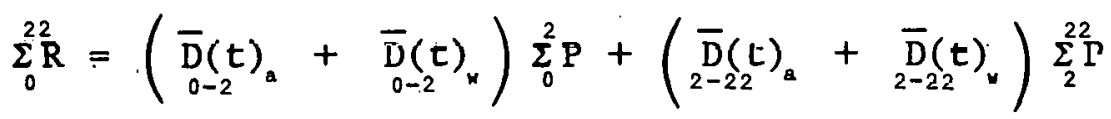

where $\sum_{0}^{22} \mathrm{R}=$ person-rem within $22 \mathrm{mi}$

$$
\sum_{0}^{2} \mathrm{P}=\text { population from } 0 \text { to } 2 \mathrm{mi}=14,700
$$


Note

$$
\sum_{2}^{22} \mathrm{P}=\text { population from } 2 \text { to } 22 \mathrm{ml}=1,066,302
$$

The total person-rem from $0-22 \mathrm{ml}$ is equal to 64 person-rem in addition to background. Based on diffusion model calculations, the remaining population from 22 to $50 \mathrm{mi}$ is not receiving dose from tritium (oxide) releases from Mound Laboratory; therefore, the total person-rem from $0-50 \mathrm{ml}(80 \mathrm{~km})$ from tritium (oxide) releases from Mound Laboratory is equal to 64 person-rem.

For comparison, the person-rem values from natural radiation, including cosmic rays and terrestrial radiation, would be approximately 320,000 person-rem for the $0-50 \mathrm{mi}$ range. ${ }^{21}$. The dose commitment due to natural background tritium is 82 person-rem for the 0-50 mi range.

\section{Acknowledgement}

The authors gratefully acknowledge the efforts of L. C. Hopkins in collecting the radiological data and $\mathrm{R}$. Brown in collecting the nonradiological data contained in this report. The authors also gratefully acknowledge the efforts of J. S. Madachy in the preparation of the preliminary atmospheric deposition estimate of plutonium-238 included in this report. 


\section{References}

1. Statistical Abstracts of Ohio - -1969, Economic Research Division, State of Ohio, March 1969, p. 6.

2. Report for Consultation on the Metropolitan Dayton Intrastate Air Quality Control Region, U.S. Department of Health, Education and Welfare, Public Health Service, Consumer Protection and Environmental Health Service, National Air Pollution Control Administration, September 1969, p. 11.

3. 40 CFR 133, Environmenta1 Protection Agency Regulations on Secondary Treatment. Information.

4. R. G. Menzi1, "Soil-Plant Relationship of Radioactive Elements," Health Physics, 11, 1325-1332 (1965).

5. D. R. Rogers, Mound Laboratory Environmental Plutonium Study - 1974, MLM-2249 (September 15, 1975), 142 pp.

6. Environmental Quarterly, HASL-298, New York Operations Office, Health and Safety Lab. (January 1, 1976), pp. B-116, B-117, B-118.

7. W. E. Sheehan, M. L. Curtis, and P. C. Carter, Development of a Low Cost Versatile Method for Measurement of HTO and HT in Air, MLM-2205 (February 14, 1975), 15 Pp.

8. ERDA Manua1 Chapter 0524 .

9. Environmental Radioactivity Surveillance Guide, ORP/SID, 72-2, U.S. Environmental Protection Agency, Office of Radiation Programs, June 1972 .

10. M. J. Taras et a1. (ed), Standard Methods for the Examination of Water and Waste Water, Thirteenth edition, American Public Health Association, Washington, D. C., 1971, 874 pp.

11. TN-48, The Miami Conservancy District, October 1975, p. 4.

12. Fa1lout Program Quarterly Report, HASL-281, New York Operations Office, Health and Safety Lab. (April 1, 1974), pp. B-104 and B-105. 
13. U.S. Environmental Protection Agency, Office of Radiation Protection, Radiation Data and Reports, Vo1. 15, Numbers 5, 6 , 9 , and 10,1974 .

14. D. Edgington, Argonne National Laboratory, "The Behavior of Plutonium in the Miami River Watershed," Private Communication in regard to Schedule 189.

15. A. P. Hul1, Health Physics and Safety Division, Brookhaven National Laboratory, Private Communication, June 28, 1974.

16. U.S. Environmental Protection Agency, Office of Radiation Protection, Radiation Data and Reports, Vo1. 15, Number 8 (August 1974), p. 502 .

17. "Report of International Commission on Radiological Protection Committee II on Permissible Dose for Internal Radiation (1959)," Health Physics, 3 , 15 (1960).

18. International Commission on Radiological Protection, "Progress Report from ICRP," Health Physics, 17, 389 (1969).

19. Basic Radiation Protection Criteria, National Council on Radiation Protection and Measurements, Report No. 39 (January 15, 1971), p. 83.

20. D. Bruce Turner, Workbook of Atmospheric Dispersion Estimates, AP-26, U.S . Environmental Protection Agency (July 1971), p. 14.

21. D. G. Carfagno and B. Robins on, Annual Environmental Monitoring Report: Calendar Year 1974, MLM-2232 (Apri1 30, 1975), 40 pp.

22. ICRP Task Group on Lung Dynamics, "Deposition and Retention Models for Internal Dosimetry of the Human Respiratory Tract," Health Physics, 12, 173 (1966).

23. Internationa1 Commission on Radiological Protection (ICRP), The Metabolism of Compounds of Plutonium and Other Actinides, ICRP Publication 19, Pergamon Press, New York (1972). 


\section{Appendix}

\section{APPLICABLE STANDARDS}

\section{RADIOACTIVE STANDARDS}

In conformance with ERDA Manual Chapter 0524, "Standards for Radiation Protection," off-site sample results are compared with RCG's established for the general population. These RCG's are derived by dividing the RCG's for an uncontrolled area by 3 .

On-site sample results are compared with the uncontrolled area RCG's which are applicable for individuals in the population.

The RCG values (in microcuries per milliliter - $\mu \mathrm{Ci} / \mathrm{ml}$ ) used for comparison purposes for the various types of samples in this report are listed below. In all cases, these are the most restrictive RCG's.

\section{Plutonium-238 (Soluble Form)}

Air

General Population

Uncontrolled Area

(Individuals in the Population)

Water

Genera1 Population

Uncontrolled Area

(Individuals in the Population)
$2 \times 10^{-14} \mu \mathrm{Ci} / \mathrm{ml}$

$7 \times 10^{-14} \mu \mathrm{Ci} / \mathrm{m} 1$

$2 \times 10^{-6} \mu \mathrm{Ci} / \mathrm{m} 1$

$5 \times 10^{-6} \mu \mathrm{Ci} / \mathrm{m} 1$

\section{Tritium (Soluble Form)}

Air

Genera1 Population

$7 \times 10^{-8} \mu \mathrm{Ci} / \mathrm{m} 1$ 
Uncontrolled Area

(Individuals in the Population)

\section{Water}

General Population

Uncontrolled Area

(Individuals in the Population)
$1 \times 10^{-3} \mu \mathrm{Ci} / \mathrm{m} 1$

$2 \dot{\mathrm{x}} 10^{-7} \mu \mathrm{Ci} / \mathrm{m} 1$

$3 \times 10^{-3} \mu \mathrm{Ci} / \mathrm{m} 1$

Foodstuffs There are no RCG values specified for foodstuffs.

Soil There are no guidelines established for radioactive species in soil.

NONRADIOACTIVE STANDARDS

Water Region $\mathrm{V}$ of the USEPA has issued a discharge permit under NPDES regulations covering both of the Mound Laboratory liquid effluent streams. The discharge limitations for each effluent stream are as follows :

Outfa11 Number 001

Flow $\left(10^{6}\right.$ gal/day)

BOD-5 Day (mg/1)

Suspended Solids (mg/1)

Dissolved Oxygen (mg/1)

Residual Chlorine (mg/1)

$0 i 1$ and Grease (mg/1)

Fecal Coliform (No./100 m1)

Fecal Coliform (No./100 ml)
pH

Outfa11 Number 002

Flow $\left(10^{6}\right.$ ga1/day)

Suspended Solids (mg/1)

Dissolved Oxygen

Oct.-April (mg/1)

May-S ept . (mg/1)

Residual Chlorine (mg/1)

Dissolved Solids (mg/1)

Oil and Grease (mg/1)

$\mathrm{pH}$
Daily

Average

0.53

30

30

5

200

6-9
Daily

Maximum

0.92

45

45

$-$

0.8

10

400

\section{as}

$\begin{array}{cc}0.53 & -- \\ 20 & 25 \\ \geq 8 & -- \\ \geq 5 & -- \\ 2000 & 0.1 \\ & 3000 \\ & 10\end{array}$


The Ohio EPA has established Water Quality Standards (EP-1-EP-9). The standards listed below are exerpted from these regulations.: These standards are stream standards and apply to a stream beyond a suitable mixing zone permitted for discharges. They should not be compared with effluent concentrations.

Average Concentration $(\mathrm{mg} / 1)$

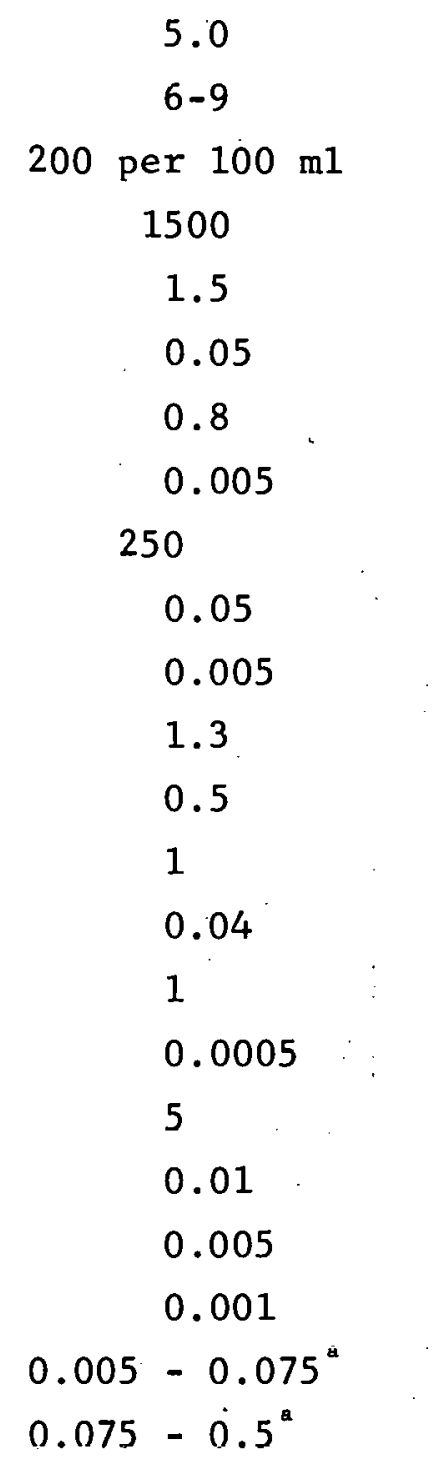

.0

er $100 \mathrm{~m} 1$

50

1.3

0.5

0.0005

0.001

\section{Constituent}

Dissolved Oxygen

$\mathrm{pH}$

Fecal Coliform

Dissolved Solids

Ammonia

Arsenic

Barium

Cadmium

Chloride

Chromium (Hexavalent)

Cyanide (Free)

Fluoride

Foaming Agents (MBAS)

Iron

Lead

Manganese

Mercury

$0 i 1 \&$ Grease

Phenols

Selenium

Silver

Copper

Zinc
${ }^{\mathrm{a}}$ Dependent on $\mathrm{CaCO}_{3}$ hardness . 


\section{Distribution}

\section{EXTERNAL}

TID-4500, UC-41 (222)

\section{Consultants}

C. F. Curtiss

University of Wisconsin

C. F. Eck

Miamisburg, Ohio

D. F. Griffing

Miami University

J. H. Leonard

University of Kentucky

H. W. Mattson

Monsanto Company

R. E. Miers

Ft. Wayne, Indiana

W. E. Moddeman

University of Dayton

G. E. Powe 11

Ohio State University

A. Shapiro

University of Cincinnati:

H. F. Swift

Univ. of Dayton Research Institute

D. White

University of Pennsylvania
Montgomery County Combined General Health District

William M. Auberle Supervisor, Air Pollution Control

David B. Penden

Director, Environmental Health

Dr. Robert A. Vogel

Health Commissioner

Other County and City Departments

Dr. Kenneth Arn

Director, Public Health

City of Oakwood

James Gibson

Chief Sanitarian

City of Kettering

Paul Asmussen

Director of Public Health

City of Middletown

Thomas Saygers

Ass't. Superintendent of Water

Supply \& Treatment

Department of Water

City of Dayton

Andrew Sabol, Jr. Director of Public Health

City of Hamilton

Benton Wah1

Health Commissioner

Warren County 
Other County and City Departments (continued)

Gene Cronk

County Sanitary Engineer

Montgomery County

Dr. Arnold Leff

Health Commissioner

City of Cincinnati

David Morgan

Village Engineer

Springboro

John R. Harvey

Butler County Health Commissioner

Hamilton, Ohio

Miami Conservancy District

Douglas G. Whitaker

Water Resources Administrator

State of Ohio

Charles W. Forsthoff, Chief

SW District Office, Ohio EPA

James Wynd

Engineer-in-Charge

Radiological Health Unit

Ohio Department of Health

Ned E. W111lams, Director

Ohio EPA

Dr. Stanley Weissman, Chairman

Environmental Board of Reviews

Dr. John H. Ackerman

Director

Ohio Department of Health

Andrew Turner, Chief

Div. of Industrial Waste

Ohio EPA

Ernest C. Nea1, Chief

Office of District Operations

Ohio EPA
Thomas Birch, Chief

Ambient Surveillance \& Bio Lab Ohio. EPA

Major General James C. Clem Adjutant General

Co1. Frank Ruvio, Jr., Director

Ohio Disaster Services Agency

Ear1 Richards

Asst. Director

Ohio EPA

Paul Flanigan, Chief

Div. of Wastewater Pollution Contro1

Ohio EPA

James Kennedy

Power Siting Commission

National Environ. Research Center U.S. EPA

Dr. Richard Blanchard

Director, Radiochemistry \& Nuclear

Engineering Research Laboratory

Ernie Minor, Director

Public Affairs

Gilbert Gigliotti, Director

Technical Information

Washington, D.C., U.S. EPA

James Martin

Waterside Ma11

Jay S. Silhanik

Sanitary Engineer

Ohio District Office U.S. EPA

William L. West, Director

Ohio District office 
Region V (Chicago), U.S. EPA

Donald Wallgren

Deputy Director

Surveillance \& Analysis Division

Ron Mustard, Chief

Federa1 Facilities Branch

Irving Bernstein

Surveillance \& Analysis Division

Monsanto Co., St. Louis

Dr. Car1 D. Boh1

Industrial Hygienist

Corporate Medical Department

Margaret E. Madden

Research Center

Corporate Research Department

Russe11.L. Miller

Safety \& Property Protection

Corporate Engineering Department

Howard K. Nason (3)

President

Monsanto Research Corporation

Monsanto Research Corporation, Dayton

Dr. Edgar E. Hardy, Director

Dr. William H. Hedley

Manager, Environ. Control Section

Dr. R. C. Binning

Asst. Director of Research

\section{Other Monsanto}

Mr. S. Turover, Director

Public \& Environ. Affairs-Europe

Monsanto Europe S.A.

Gerald Osterman

Engineering Service Superintendent
ERDA $\cdot$ Headquarters

Waiter G. Belter

Sr. Environmental Engineer

Div. Biomed. \& Environ. Research

Maj. General Joseph K. Bratton

Director, Div. of Military

Application

Maj. General E. B. Giller

Deputy Ass't. Administrator for

National Security

John W. King, Director

Office of Public Affairs

Dr. Lawrence E. Killion, Chief

Isotope Separation Branch

Div. of Military Application

Dr. F. C. Gilbert

Deputy Director

Div. of Military Application

ERDA, ALO

W. R. Cooper, Ass't. Manager

Office of Plans \& Budgets

George Dennis, Director

Public Affairs Division

H. E. Roser, Manager

Leonard A. Jacobvitz

Chief Counsel

R. R. Fredlund

Acting Director

Classification \& Technical Information Division

John F. Burke

Ass't. Manager

office for Operations

Jack R. Roeder, Director

Operational Safety Division

James E. Randa11, Attorney 
Other ERDA

J.A. Chacon, Manager

Dayton Area Office

Dr. Herbert I. Volchok

Health \& Safety Laboratory

\section{Other ERDA Contractors}

Dr. Joseph F. Tinney

Hazards Control Dept. Head

University of California

Lawrence Livermore Laboratory

Dr. George L. Voelz

Health Division Leader

University of California

Los Alamos Scientific Laboratory

Dr. H. M. Agnew, Director

University of California

Los Alamos Scientific Laboratory

R. D. Baker, Division Leader

Chemistry - Materials Science Div. University of California

Los Alamos Scientific Laboratory

Duane C. Sewe11

Deputy Director

University of California

Lawrence Livermore Laboratory

L. Gutierrez, Director

Systems Development

Sandia Laboratories, Livermore

Robert Jordan, Manager, Hea1th

Safety and Environ. Protection

Union Carbide Corp.

Jack S. Marsha11

Head Ecologica1 Sciences Section Radiological \& Environ. Research Div. Argonne National Laboratory

W. J. Howard, Executive Vice Pres. S andia Laboratories, Albuquerque
L. M. Jercinovic, Dept. Mgr.

Safety Standards \& Engineering

Sandia Laboratories, Albuquerque

C. P. McKay

Environ. \& Health Services

The Bendix Corporation

E. P. Forest, Manager

Environ. Health \& Safety

General Electric Company

R. E. Yoder, Director

Health, Safety \& Environment

Rockwe11 International

W. H. Kingsley, Dept. Manager

Environ. Health

Sandia Laboratories, Albuquerque

D. P. O'Nei1, Director

Occupational Health \& Safety

Argonne National Laboratories

J. D. McLendon

Radiation Safety \& Ind. Hygiene

Union Carbide Corp.

Donald A. Mckown

Health Physicist - Radioactive

Safety Office

Battelle Memoria1 Institute

Andrew P. Hull

Environ. Monitoring Supervisor

HP \& Safety Division

Brookhaven Nationa1 Laboratory

J. W. McCaslin, Branch Manager

Safety Standards

Aerojet Nuclear Co.

Dr. W. J. Bair, Manager

Biomedical and Environmental

Research Program

Battelle, Pacific Northwest Lab.

J. J. Fix

Occupational and Environmental

Safety Department

Battelle, Pacific Northwest Lab. 
Other ERDA Contractors (continued):

J. P. Corley

Occupationa1 and Environmental

Safety Department

Battelle, Pacific Northwest Lab.

C. M. Patterson

Superintendent, Health Physics

E. I. duPont deNemours \& Co.

Herman Phillips

Health and Safety Director

Mason \& Hanger - Silas Mason

Company, Inc.

Dr. Edward J. Cleary

Kettering Laboratory.

University of Cincinnati

R. C. Heatherton

Director of Health \& Safety

National Lead Company of Ohio

Ralph F. Hoffer

Manager, Health \& Safety

Energy Systems Program

General Electric Company

Vergil S. Emler

Supt. General Safety \& Environ. Management

Goodyear Atomic Corporation

Special Consultants

Col. Lawrence T. Odland

Radiological Health Laboratory

United States Air Force

Dr. Eugene L. Saenger

University of Cincinnati

Dr. Lawrence Wilding

Ohio State University

Dr. McDonald E. Wrenn

New York University Medica1 Center

\section{INTERNAL}

P. C. Adams

A. G. Barnett

B. E. Baughn

R. T. Braun

J. E. Bradley

D. G. Carfagno (100)

W. T. Cave

H. I. Charbeneau

D. A. Edling

F. M. Farmer

R. K. Flitcraft/J.R. McClain

W. E. Huffman

C. H. Huntington

L. V. Jones

D. P. Ke1ly

H. E. Meyer

E. J. Reagan

B. Robinson

H. L. Turner

R. E. Vallee

A. F. Vollmer

W. H. Westendorf

H. L. Williams

Publications

Records Management

Library (15) 